Article

\title{
Recuperative Amino Acids Separation through Cellulose Derivative Membranes with Microporous Polypropylene Fiber Matrix
}

\author{
Aurelia Cristina Nechifor ${ }^{1}$, Andreia Pîrțac ${ }^{1}$, Paul Constantin Albu ${ }^{2}$, Alexandra Raluca Grosu ${ }^{1, *(D),}$ \\ Florina Dumitru ${ }^{3} \mathbb{D}$, Ioana Alina Dimulescu (Nica) ${ }^{1}$, Ovidiu Oprea ${ }^{3} \mathbb{D}$, Dumitru Pascu ${ }^{1}$, Gheorghe Nechifor $^{1} \mathbb{D}^{\mathbb{D}}$ \\ and Simona Gabriela Bungău 4 (D)
}

Citation: Nechifor, A.C.; Pîrțac, A.; Albu, P.C.; Grosu, A.R.; Dumitru, F.; Dimulescu (Nica), I.A.; Oprea, O.;

Pașcu, D.; Nechifor, G.; Bungău, S.G. Recuperative Amino Acids

Separation through Cellulose

Derivative Membranes with Microporous Polypropylene Fiber Matrix. Membranes 2021, 11, 429. https://doi.org/10.3390/

membranes11060429

Academic Editor: Isabel C. Escobar

Received: 29 April 2021

Accepted: 3 June 2021

Published: 5 June 2021

Publisher's Note: MDPI stays neutral with regard to jurisdictional claims in published maps and institutional affiliations.

Copyright: (C) 2021 by the authors Licensee MDPI, Basel, Switzerland. This article is an open access article distributed under the terms and conditions of the Creative Commons Attribution (CC BY) license (https:/ / creativecommons.org/licenses/by/ $4.0 /)$.
1 Analytical Chemistry and Environmental Engineering Department, University Politehnica of Bucharest, 1-7 Polizu St., 011061 Bucharest, Romania; aureliacristinanechifor@gmail.com (A.C.N.); andreia.pascu@yahoo.ro (A.P.); oanaalinadimulescu@yahoo.com (I.A.D.); dd.pascu@yahoo.com (D.P.); ghnechifor@gmail.com (G.N.)

2 IFIN Horia Hulubei, Radioisotopes and Radiation Metrology Department (DRMR), 30 Reactorului St., 023465 Măgurele, Romania; paulalbu@gmail.com

3 Department of Inorganic Chemistry, Physical Chemistry and Electrochemistry, University Politehnica of Bucharest, 1-7 Polizu St., 011061 Bucharest, Romania; d_florina@yahoo.com (F.D.); ovidiu73@yahoo.com (O.O.)

4 Faculty of Medicine and Pharmacy, University of Oradea, Universităţii St., no.1, Bihor, 410087 Oradea, Romania; simonabungau@gmail.com

* Correspondence: alexandra.raluca.miron@gmail.com

Abstract: The separation, concentration and transport of the amino acids through membranes have been continuously developed due to the multitude of interest amino acids of interest and the sources from which they must be recovered. At the same time, the types of membranes used in the separation of the amino acids are the most diverse: liquids, ion exchangers, inorganic, polymeric or composites. This paper addresses the recuperative separation of three amino acids (alanine, phenylalanine, and methionine) using membranes from cellulosic derivatives in polypropylene ma-trix. The microfiltration membranes (polypropylene hollow fibers) were impregnated with solu-tions of some cellulosic derivatives: cellulose acetate, 2-hydroxyethyl-cellulose, methyl 2-hydroxyethylcelluloseand sodium carboxymethyl-cellulose. The obtained membranes were characterized in terms of the separation performance of the amino acids considered (retention, flux, and selectivity) and from a morphological and structural point of view: scanning electron microscopy (SEM), high resolution SEM (HR-SEM), Fourier transform infrared spectroscopy (FT-IR), energy dispersive spectroscopy (EDS) and thermal gravimetric analyzer (TGA). The re-sults obtained show that phenylalanine has the highest fluxes through all four types of mem-branes, followed by methionine and alanine. Of the four kinds of membrane, the most suitable for recuperative separation of the considered amino acids are those based on cellulose acetate and methyl 2-hydroxyethyl-cellulose.

Keywords: amino acids; cellulose derivatives; polypropylene hollow fibers; impregnated membranes; amino acid separation; membrane processes

\section{Introduction}

Amino acids are substances whose biological role, when incorporated into protein molecules, neurotransmitters, or hormones and in precursors of other molecules, has led to a continuous development of fundamental and applied research [1,2]. The simultaneous presence in the molecule of amino acids, of a basic, amino group $\left(-\mathrm{NH}_{2}\right)$ but also of an acid group, carboxyl (-COOH), close spatially (Figure 1a), gives these substances unique physical-chemical and biological properties [3,4]. Of course, one of the important aspects of this structure is given by the presence of electrical charges in amino acids [5-7], regardless 
of the $\mathrm{pH}$ of the aqueous solution in which they are found (Figure 1b). Simultaneously, the chemical properties of the amino and carboxyl groups make the amino acids the molecules of greatest interest in modifying, by grafting, the properties of various organic and inorganic materials [8-11].<smiles>[R]C(N)C(=O)O</smiles>

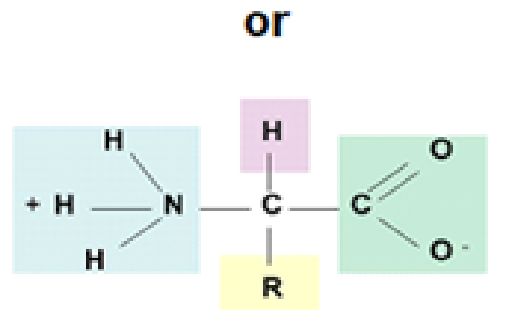

(a)

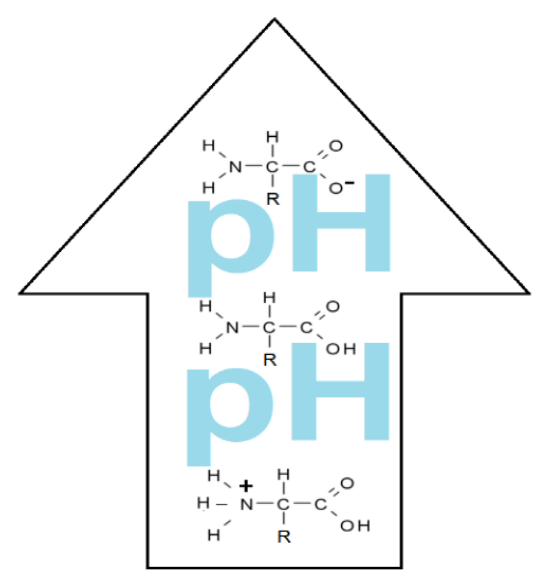

(b)

Figure 1. The chemical structure of amino acids (a) and the ionic forms depending on the $\mathrm{pH}$ of aqueous solution in which they are found $(\mathbf{b})$.

All these characteristics, but also the multiple chemicals, biological and biomedical applications make it necessary to recover amino acids from any source, even when their concentration is low [12-17].

The properties of an amino acid will also be influenced by the $\mathrm{R}$ group, which can give the molecule specific interactions: hydrophobic, hydrophilic, or redox, depending on the atoms that make it up $[18,19]$. All these characteristics of amino acids allowed researchers to address the most varied techniques and methods of separation, among which some of those involving membranes are presented in Table 1 [20-59].

Table 1. Membrane amino acids separation techniques and methods.

\begin{tabular}{ccc}
\hline Methods or Techniques & Gradient & Refs. \\
\hline Dialysis (D), Hemodialysis (HD) & $\Delta \mathrm{c}$ & {$[20-22]$} \\
\hline Ion-exchange membranes (IEM) & $\Delta \mathrm{c}, \Delta \mathrm{E}$ & {$[23-25]$} \\
\hline Electro dialysis (ED) & $\Delta \mathrm{E}$ & {$[26,27]$} \\
\hline Electro-ultrafiltration (EUF) & $\Delta \mathrm{E}, \Delta \mathrm{p}$ & {$[28-33]$} \\
\hline Ultrafiltration (UF) & $\Delta \mathrm{p}$ & {$[34-37]$} \\
\hline Nanofiltration (NF) & $\Delta \mathrm{p}$ & {$[38-43]$} \\
\hline Molecularly imprinted polymeric membranes (MIPM) & $\Delta \mathrm{p}$ & {$[44]$} \\
\hline Liquid membranes (LM) & $\Delta \mathrm{c}$ & {$[45-47]$} \\
\hline $\begin{array}{c}\text { Other processes (Adsorption, Polyelectrolyte nanoparticles, } \\
\text { Composite membranes, Combined processes, } \\
\text { Molecular recognition) }\end{array}$ & $\Delta \mathrm{c}, \Delta \mathrm{E}, \Delta \mathrm{p}$ & {$[48-59]$} \\
\hline
\end{tabular}

Sources of amino acid are among the most diverse, but mainly hydrolysates in the food industry have been addressed: milk, meat, fish, wine, or animal skin processing, agriculture, and biotechnology.

Each method or process of membrane separation, concentration, or purification of amino advantages and disadvantages and must be correlated with the processing system, so as to meet both selectivity and productivity requirements [60]. 
However, we must mention some of the specific performances of the membrane processes, which make them extremely attractive for the separation of compounds of biological interest such as the amino acids [51-60]:

- High selectivity;

- $\quad$ Productivity guided by membrane design;

- Accessible operating parameters;

- $\quad$ Raising the scale without multiplying the problems of chemical engineering;

- $\quad$ Reduced volume of installations;

- Access to the treatment of coarse and viscous dispersed systems;

- Minimizing of the consumption of chemical reagents and auxiliary materials;

- $\quad$ Reduced investments for the realization of the auxiliary systems;

- Complete automation;

- Possibility to operate in isolate or hard to reach locations;

- Favorable economic ratio, operating costs: product quality.

From the perspective of the application of the presented membrane processes (Table 1) for membrane separation of amino acids, they can be approached as follows:

- $\quad$ high flows and productivity [23-27],

- $\quad$ simplicity and robustness of the installations [28-43],

- $\quad$ or their selectivity [44-47].

The membranes can also be chosen according to selectivity and flow criteria [61-63], but in terms of biocompatibility, accessibility and cost the cellulose based membranes remain the most studied and applied $[64,65]$.

This paper addresses the recuperative separation of three amino acids (alanine, phenylalanine, and methionine) from synthetic solutions, using membranes from cellulosic derivatives (cellulose acetate, 2-hydroxyethyl-cellulose, and methyl 2-hydroxyethyl-cellulose or sodium carboxymethyl-cellulose) in polypropylene hollow fiber matrix.

\section{Materials and Methods}

\subsection{Materials}

\subsubsection{Chemicals}

The materials used in the present work were of analytical purity. They were purchased from Merck (Merck KGaA, Darmstadt, Germany): sodium hydroxide $(\mathrm{NaOH})$ and hydrochloric acid solution $(\mathrm{HCl}, 35 \%)$.

The amino acids (alanine, phenylalanine and, methionine) and the cellulose derivatives (cellulose acetate (Product of USA), 2-hydroxyethyl-cellulose (product of USA), methyl 2-hydroxyethyl-cellulose (product of Belgium) and sodium carboxymethyl-cellulose (Product of USA)) were purchased from Aldrich Chemistry (Merck KGaA, Darmstadt, Germany).

The purified water, characterized by a conductivity of $18.2 \mu \mathrm{S} / \mathrm{cm}$, was obtained with a RO Millipore system (MilliQR Direct 8 RO Water Purification System, Merck, Darmstadt, Germany).

\subsubsection{Membrane Support}

The hollow fibers polypropylene support membranes (PPM) were provided by GOST Ltd., Perugia, Italy. Their characteristics are presented in Figure $2[66,67]$. 


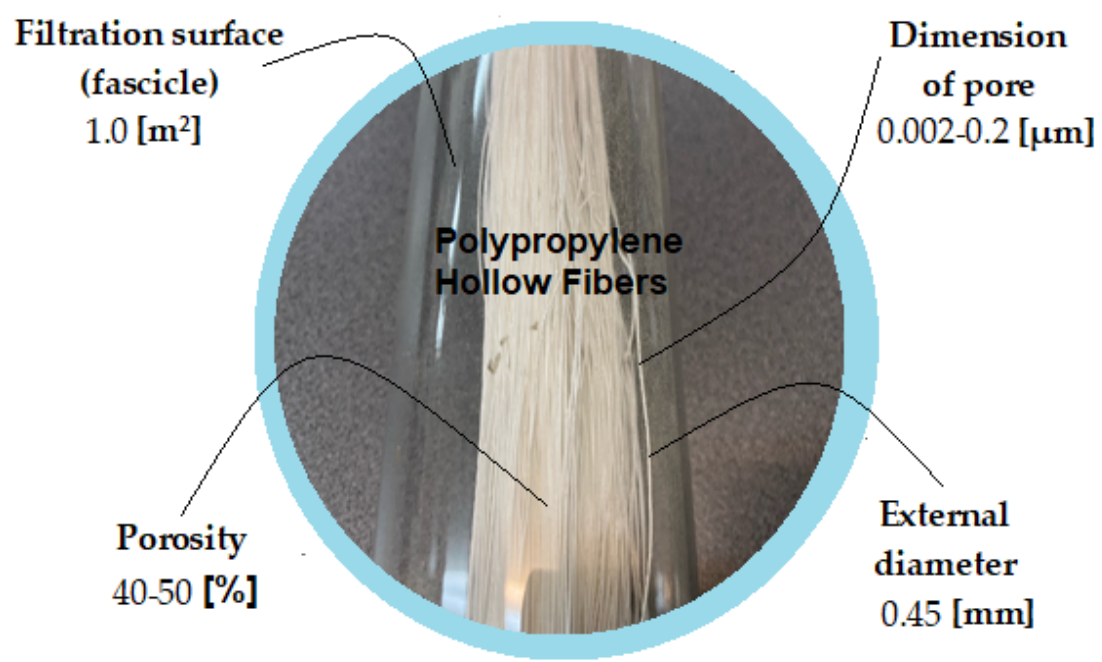

Figure 2. The characteristics of the hollow fibers polypropylene support membranes (PPM).

\subsection{Impregnated Cellulose Derivatives Polypropylene Membrane Preparation (Cell-D-PPM)}

2.2.1. Obtaining the Cellulose Derivatives Solution

The cellulosic derivatives (cellulose acetate, 2-hydroxyethyl-cellulose, methyl 2-hydroxyethyl-cellulose or sodium carboxymethyl-cellulose), having the characteristics indicated in Table 2, were solubilized in a mass concentration of $2 \%$, in a mixture of methylene chloride:methyl alcohol $=2: 1$.

For this, the glass vessel in which the mixture of solvents and the corresponding amount of polymer were introduced, was placed in an ultrasonic bath (Elmasonic S, Elma Schmidbauer $\mathrm{GmbH}$, Singen, Germany) for four hours, observing the complete dispersion and obtaining the polymeric solution. The obtained solutions were filtered using a metal sieve with $40 \mu \mathrm{m} \times 40 \mu \mathrm{m}$ meshes and then placed in closed containers for $24 \mathrm{~h}$ in order to remove bubbles.

2.2.2. Obtaining Cellulose Derivatives Impregnated on Polypropylene Fibers Membranes (Cell-D-PPM)

For impregnation of support hollow fiber membranes, the polymer solution was placed in a glass cylindrical vessel with measured capacity and then the fiber bundle was immersed (Figure 3) with the heads out of the solution and coupled to a preliminary vacuum pump $[68,69]$. The fibers were coupled to the vacuum pump to remove the air and when the pressure difference increased, the pump switched-off automatically. The system was maintained in this state for $10 \mathrm{~min}$, after which the impregnated fibers were removed above the polymer solution. After $30 \mathrm{~min}$, the fibers were placed in the vacuum oven, at $60{ }^{\circ} \mathrm{C}$, to remove the solvent mixture. After this stage, the fibers were placed in a $1 \mathrm{~L}$ vessel with deionized water and after about an hour, they could be used in the permeation process. Four types of membranes were obtained, symbolized according to Table 2. 
Table 2. The characteristics of cellulosic derivatives under test and the membranes obtained.

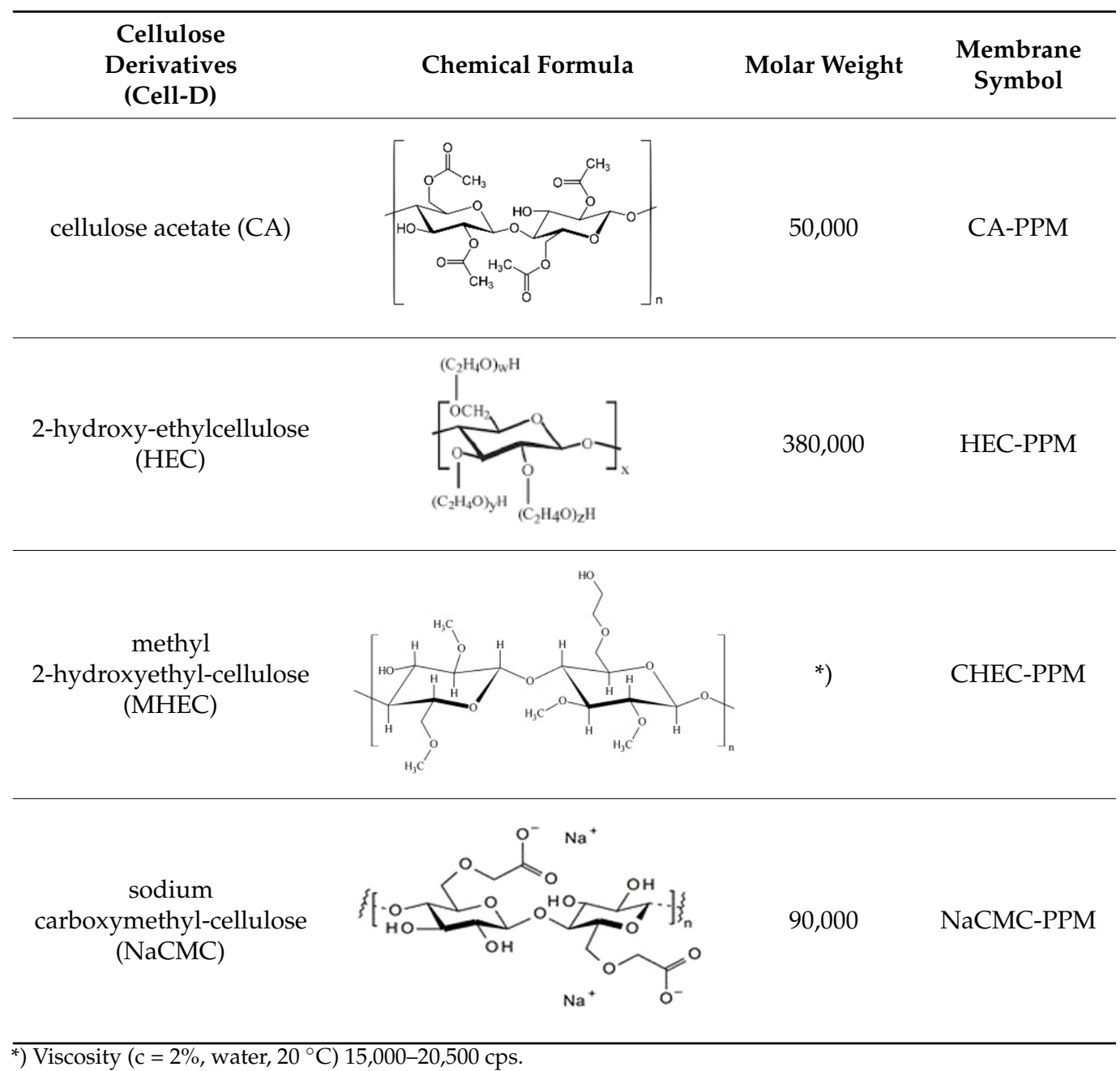

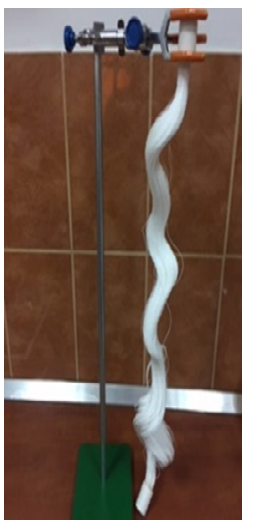

(a)

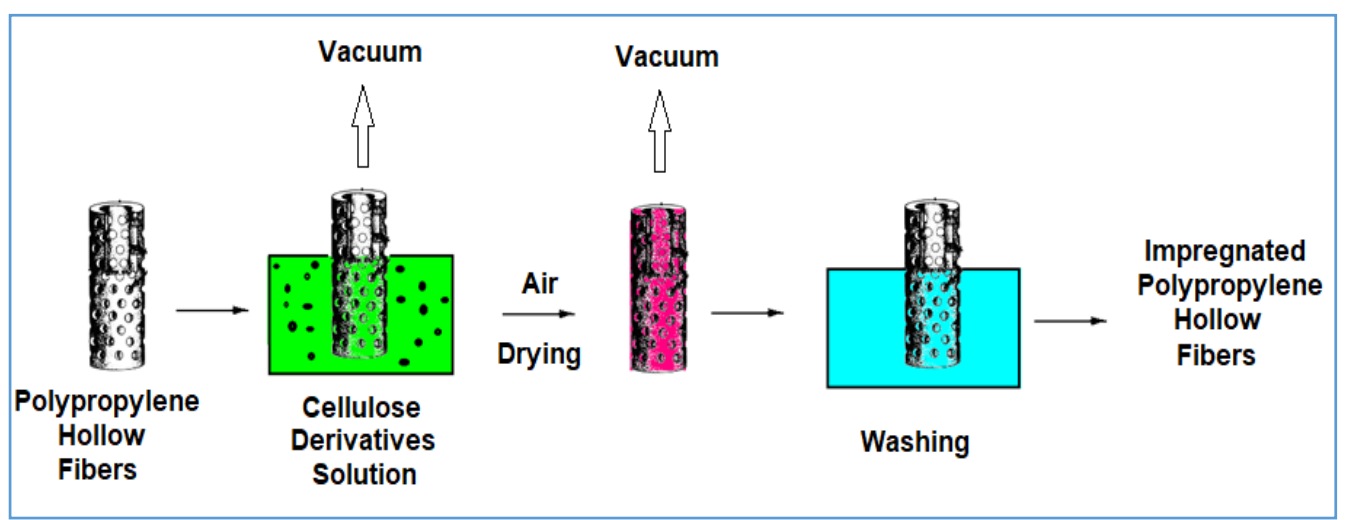

(b)

Figure 3. Schematic depiction of the impregnation procedure: (a) hollow polypropylene fiber bundles; and (b) scheme of the stages of the impregnation procedure.

\subsection{Permeation Procedures}

In the source phase (SP) the synthetic solution of the considered chemical species (amino acids-Table 3), with a concentration of $0.150-0.250 \mathrm{~mol} / \mathrm{L}$, is introduced in the installation (Figure 4). The $\mathrm{pH}$ of the source phase is made with hydrochloric acid solution $0.01 \mathrm{~mol} / \mathrm{L}$, deionized water, or sodium hydroxide $0.1 \mathrm{~mol} / \mathrm{L}$. The receiving phase (RP) is 
formed in all cases from deionized water. The volume of the source phase is $10 \mathrm{~L}$, and of the receiving phase is $1 \mathrm{~L}$. The operating flows are the same for all experiments, for operational reasons already studied [69-71]. Thus, for the source phase the flow in the pertraction module is $5 \mathrm{~L} / \mathrm{min}$, and the flow of the receiving phase is $0.1 \mathrm{~L} / \mathrm{min}$. In order to determine the amino acids separation performances, a $1 \mathrm{~mL}$ of solution is taken periodically and analyzed for spectrophotometric analysis (CamSpec Spectrophotometer) [72-74]. For the receiving phase, the operation is performed through capillaries while for the source phase the operation is performed outside the capillaries (Figure 4).

Table 3. The characteristics of the tested amino acids (at $25^{\circ} \mathrm{C}$ ).

\begin{tabular}{|c|c|c|c|c|c|}
\hline Amino Acid & Chemical Formula & $\begin{array}{l}\text { Molar Weight } \\
(\mathrm{g} / \mathrm{mol})\end{array}$ & $\begin{array}{l}\text { Solubility } \\
\text { (g/L) }\end{array}$ & $\begin{array}{l}\text { Isoelectric Point } \\
\text { (Ip) }\end{array}$ & $\begin{array}{l}\text { Acidity Constants } \\
\text { (pKa) }\end{array}$ \\
\hline Alanine & $\mathrm{NH}_{2}$ & 89.09 & 167.2 & 6.11 & $\begin{array}{c}2.35 \text { (carboxyl), } \\
9.87 \text { (amino) }\end{array}$ \\
\hline Phenylalanine & & 165.19 & 26.9 & 5.91 & $\begin{array}{c}2.58 \text { (carboxyl) } \\
9.13 \text { (amino) }\end{array}$ \\
\hline $\begin{array}{c}\text { Methionine or } \\
\text { 2-amino-4- } \\
\text { (methylthio) butanoic } \\
\text { acid }\end{array}$ & $\mathrm{NH}_{2}$ & 149.21 & 56.6 & 5.74 & $\begin{array}{l}2.28 \text { (carboxyl), } \\
9.21 \text { (amino) }\end{array}$ \\
\hline
\end{tabular}

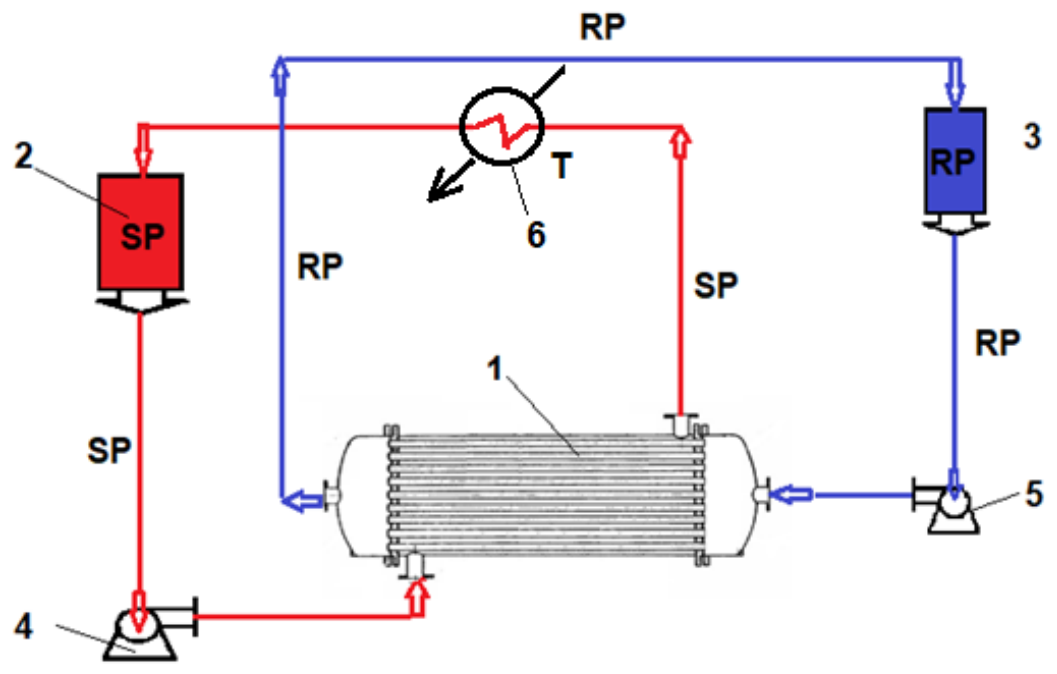

Figure 4. Depiction of the operational scheme with the pertraction module: SP - source phase, RS receiving phase. 1. Hollow fiber pertraction module; 2. SP reservoirs; 3 . RP reservoirs; 4 . SP pump; 5. RP pump; 6. T thermostat.

The fluxes from the source phase [75] were determined against the measured permeate mass within a determined time range, applying the following equation:

$$
J=\frac{M}{S \cdot t}\left(\mathrm{mg}\left(\mathrm{m}^{2} \mathrm{~s}\right)\right) \text { or }\left((\mathrm{mol})\left(\mathrm{m}^{2} \mathrm{~s}\right)\right)
$$


where: $M$-permeate mass ( $\mathrm{g}$ or $\mathrm{mol}$ ), $S$ - effective surface of the membrane $\left(\mathrm{m}^{2}\right), t$ - time (s) necessary to collect the permeate volume.

The extraction efficiency $(E E \%)$ for the species of interest using the concentration of the solutions [76] was calculated as follows:

$$
E E(\%)=\frac{\left(c_{0}-c_{f}\right)}{c_{0}} \cdot 100
$$

where: $c_{f}$-final concentration of the solute (considered chemical species), $c_{0}$-initial concentration of solute (considered chemical species).

The same extraction efficiency can also be computed based upon the absorbance of the solutions, as in:

$$
E E(\%)=\frac{\left(A_{0}-A_{s}\right)}{A_{0}} \cdot 100
$$

where: $A_{0}$-initial absorbance of sample solution, $A_{\mathrm{s}}$ — current absorbance of the sample.

\subsection{Equipment}

The microscopy studies, scanning electron microscope (SEM) and high resolution SEM (HR SEM), were performed using a Hitachi S4500 system (Hitachi High-Technologies Europe $\mathrm{GmbH}$, Mannheim, Germany). Thermal characterizations were performed using a Netzsch Thermal Analyzer (Netzsch-Gerätebau GmbH, Selb, Germany).

The thermal analysis TG-DSC for the cellulose samples $(\sim 20 \mathrm{mg})$ was performed with a Netzsch STA 449C Jupiter apparatus. The samples were placed in an open crucible made of alumina and heated with $10 \mathrm{~K} \cdot \mathrm{min}^{-1}$ from room temperature up to $900{ }^{\circ} \mathrm{C}$, under the flow of $50 \mathrm{~mL} \mathrm{~min}^{-1}$ dried air. An empty alumina crucible was used as reference.

Spectroscopy Bruker Tensor 27 FTIR with a Diamond Attenuated Total ReflectionATR (Bruker) was used to study the interactions between the chemicals used in the membranes developed. FTIR analysis was recorded in the range of 500 to $4000 \mathrm{~cm}^{-1}$. UV-VIS analysis was performed on a Spectrometer CamSpec M550 (Spectronic CamSpec Ltd., Leeds, UK). Other devices used were as follows: ultrasonic bath (Elmasonic S, Elma Schmidbauer $\mathrm{GmbH}$, Singen, Germany), vacuum oven (VIOLA—Shimadzu, Bucharest, Romania).

\section{Results and Discussion}

The separation, concentration and purification of amino acids concerns researchers from various fields of activity: chemistry, biochemistry, engineering, medicine or the environment. Remarkable results were obtained in this field through membrane processes, but further research considers both the recovery of amino acids from poor sources and the creation of physical-chemically resistant biocompatible membranes-especially for sterilization or cleaning in order to reuse or maintain process performance.

Obviously, the concern of cellulose derivatives usage for amino acid recovery through membrane processes it is understandable. These derivatives are compatible with the biological environment and biological chemical species, in our case amino acids and their bio-resources. Likewise, the cellulose derivatives have a natural, specific interaction with amino acids, and the chemical modifications of this interaction are very important. The experimental study addressed three amino acids, two of which are essential amino acids. The three amino acids have different molar weights and solubilities, but the side chain, $R$, is hydrophobic of three types: alkyl (alanine), aromatic (phenylalanine) and sulfur (methionine). The hydrophobic radical of amino acids can interact with the cellulosic membrane material. For this reason the four chosen derivatives have substituents with etheric groups (HEC, MHEC), ester (CA) or carboxylic groups (NaCMC). 


\subsection{Membranes and Material Membranes Characterization}

\subsubsection{Thermal Characteristics}

Among the physical characteristics of the membranes and membrane materials proposed for study the mechanical ones are provided by the support matrix of polypropylene hollow fiber. But in the practice of membrane processes, the working temperature as well as the temperature of regeneration-washing or of sterilization is very important. Hence, the need to determine the thermal behavior of both membrane materials and impregnated membranes obtained (Figures 5 and 6, Tables 4 and 5 as well as the Supplementary Figures S1 and S2).

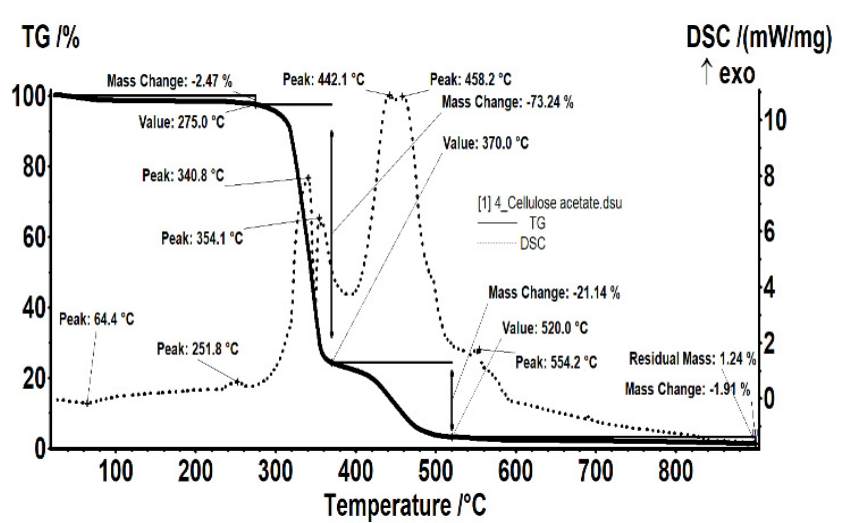

(a)

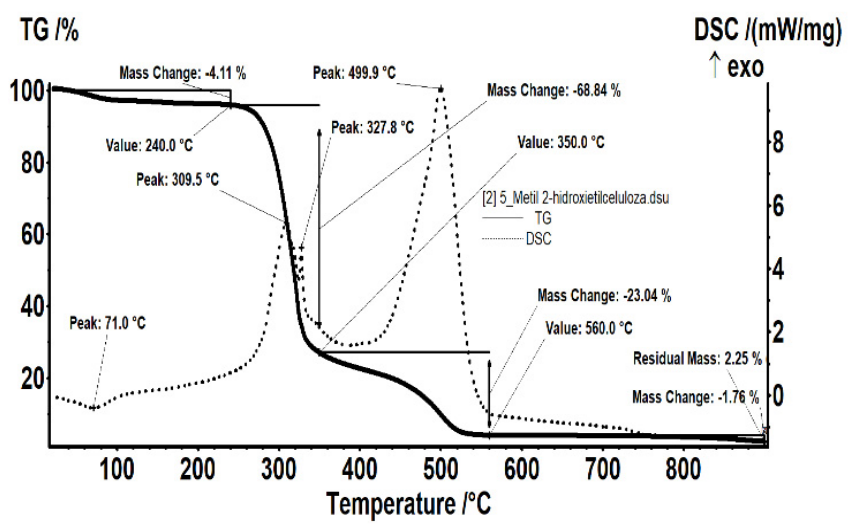

(c)

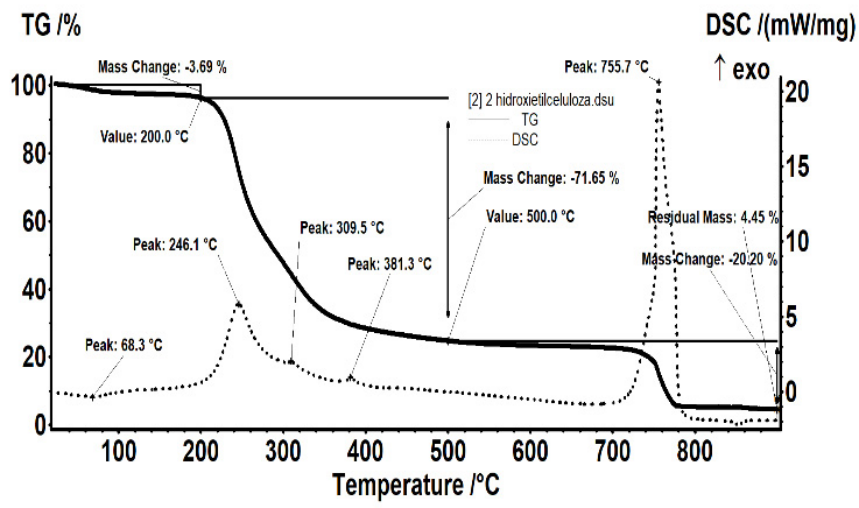

(b)

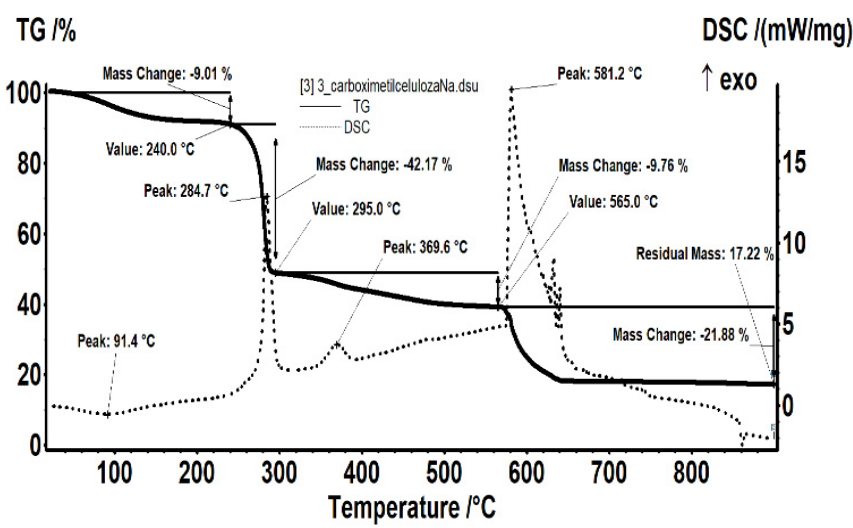

(d)

Figure 5. Thermal diagrams for: (a) cellulose acetate (CA); (b) 2-hydroxyethyl cellulose (HEC); (c) methyl 2-hydroxyethylcellulose (MHEC); (d) sodium carboxymethyl-cellulose (NaCMC).

The cellulose acetate test (Figure 5a) is thermally stable up to $275^{\circ} \mathrm{C}$. The test loses $2.47 \%$ of its initial mass, most likely due to the water (moisture) absorbed, the process being accompanied by a weak endothermic effect at $64.4^{\circ} \mathrm{C}$. A weak exothermic effect is also observed at $251.8^{\circ} \mathrm{C}$, corresponding to a process of partial oxidation of the organic molecule. Degradative oxidation starts at $275{ }^{\circ} \mathrm{C}$, the test loosing $73.24 \%$ up to $370{ }^{\circ} \mathrm{C}$. The process is accompanied by two separate exothermic peaks, at 340.8 and $354.1{ }^{\circ} \mathrm{C}$, corresponding to the degradation of the acetate and cellulose group. The carbon mass remaining after initial degradation is eliminate in the range $370-520^{\circ} \mathrm{C}$, through oxidation, the process being accompanied by an exothermic intense, wide effect, with two maxima at 442.1 and $458.2^{\circ} \mathrm{C}$.

The 2-hydroxyethyl cellulose test (Figure 5 b) loses $3.69 \%$ of its initial mass in the range RT-200 ${ }^{\circ} \mathrm{C}$, probably water absorbed by the hydroxyethyl cellulose powder. The process is accompanied by a weak endothermic effect, at $68.3^{\circ} \mathrm{C}$. After $200^{\circ} \mathrm{C}$ the main process of 
oxidative degradation takes place, the mass loose continuing slowly until $500{ }^{\circ} \mathrm{C}$. During this interval, $71.65 \%$ of the initial mass is lost. The process is accompanied by several exothermic effects with maxima at $246.1,309.5$ and $381.3^{\circ} \mathrm{C}$.

The methyl 2-hydroxyethyl cellulose test (Figure 5 c) looses $4.11 \%$ of its initial mass, most likely the absorbed water, the process being accompanied by a weak endothermic effect, with a minimum at $71{ }^{\circ} \mathrm{C}$. The degradative oxidation process took place in the interval $240-350{ }^{\circ} \mathrm{C}$, the test loosing $68.84 \%$. The process is accompanied by two separate, asymmetric, exothermic peaks at 309.5 and $327.8^{\circ} \mathrm{C}$, corresponding to the degradation of cellulose and to the lateral groups, respectively. The remaining carbon mass following the initial degradation is eliminated in the interval $350-560{ }^{\circ} \mathrm{C}$, by oxidation, the process being accompanied by an exothermic, intense, wide, asymmetric effect with the maximum at $499.9^{\circ} \mathrm{C}$.

The sodium carboxymethyl-cellulose test (Figure 5 d) looses $9.01 \%$ of its initial mass in the interval RT- $240{ }^{\circ} \mathrm{C}$, probably having a higher water content absorbed by the carboxymethylcellulose powder. The process is accompanied by a weak endothermic effect, at $91.4^{\circ} \mathrm{C}$. The main oxidative degradation takes place in the range $240-295^{\circ} \mathrm{C}(42.17 \%$ of its initial mass is eliminated), the mass loss continuing slowly until $565^{\circ} \mathrm{C}$ (another $9.76 \%$ is still eliminated). The processes are accompanied by exothermic effects with maxima at $284.7^{\circ} \mathrm{C}$ and $369.6{ }^{\circ} \mathrm{C}$. After $565^{\circ} \mathrm{C}$, there is a mass loss of $17.22 \%$ accompanied by a strong exothermic effect, with a maximum at $581.2^{\circ} \mathrm{C}$, most likely due to the decomposition of sodium carbonate and the reaction with the mass of the crucible material $\left(\mathrm{Al}_{2} \mathrm{O}_{3}\right)$.

Table 4. Main thermal characteristics of the used cellulose derivatives.

\begin{tabular}{ccccc}
\hline Sample & Water Content & $\begin{array}{c}\text { Mass Loss } \\
\mathbf{2 0 0 - 4 0 0}{ }^{\circ} \mathbf{C}\end{array}$ & $\begin{array}{c}\text { Mass Loss } \\
\mathbf{4 0 0 - 8 0 0}{ }^{\circ} \mathbf{C}\end{array}$ & Residual Mass \\
\hline $\mathrm{CA}$ & $2.47 \%$ & $76.35 \%$ & $20.31 \%$ & $1.24 \%$ \\
\hline $\mathrm{HEC}$ & $3.71 \%$ & $67.92 \%$ & $23.17 \%$ & $4.45 \%$ \\
\hline $\mathrm{MHEC}$ & $4.11 \%$ & $73.63 \%$ & $19.06 \%$ & $2.25 \%$ \\
\hline $\mathrm{NaCMC}$ & $9.02 \%$ & $47.84 \%$ & $26.28 \%$ & $17.22 \%$ \\
\hline
\end{tabular}

For impregnated membranes that have provided the best separation results (CA-PPM and MHEC-PPM), the thermal diagrams indicate behaviors close to the support fiber, but with specificities that must be taken into account, especially for operation, regeneration or thermal sterilization (Figure 6 and Table 5).

The sample PPM (Figure 6a) is relatively stable up to $180^{\circ} \mathrm{C}$, with $0.69 \%$ recorded mass loss. At the same time, a small endothermic effect is present on the DSC curve, with onset at $154.9^{\circ} \mathrm{C}$ and a peak at $165.0^{\circ} \mathrm{C}$. This effect corresponds to the melting of the polypropylene. Between 180 and $410{ }^{\circ} \mathrm{C}$ the PPM fibers suffered an oxidative degradation, the recorded mass loss being $94.06 \%$. The effects on DSC curve are a mix of endothermic (decomposing reactions) and exothermic (partial oxidation) effects, with the latest being more intense than former. In the $410-500{ }^{\circ} \mathrm{C}$ interval, the oxidation of the carbonaceous mass is achieved with a mass loss of $7.29 \%$. The process is accompanied by a strong exothermic effect, asymmetric, with a maximum at $418.0^{\circ} \mathrm{C}$. 


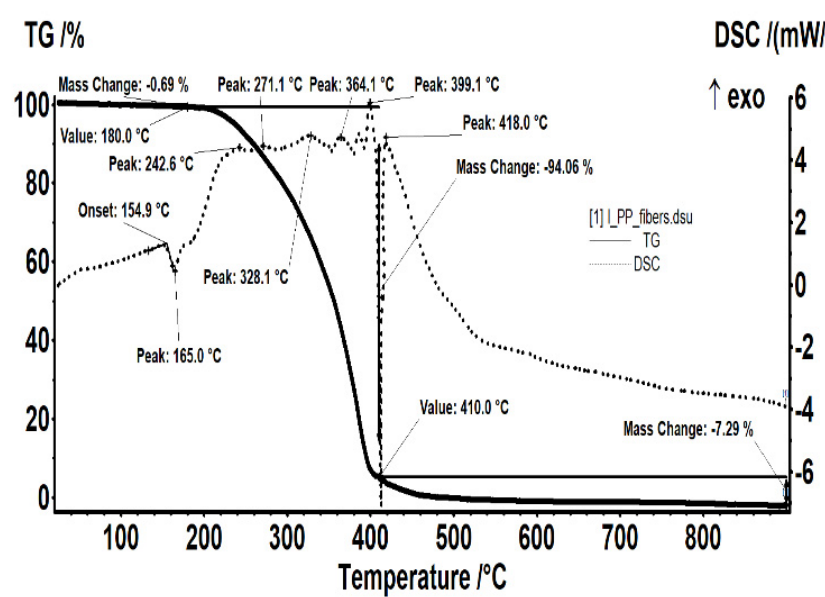

(a)

(c)

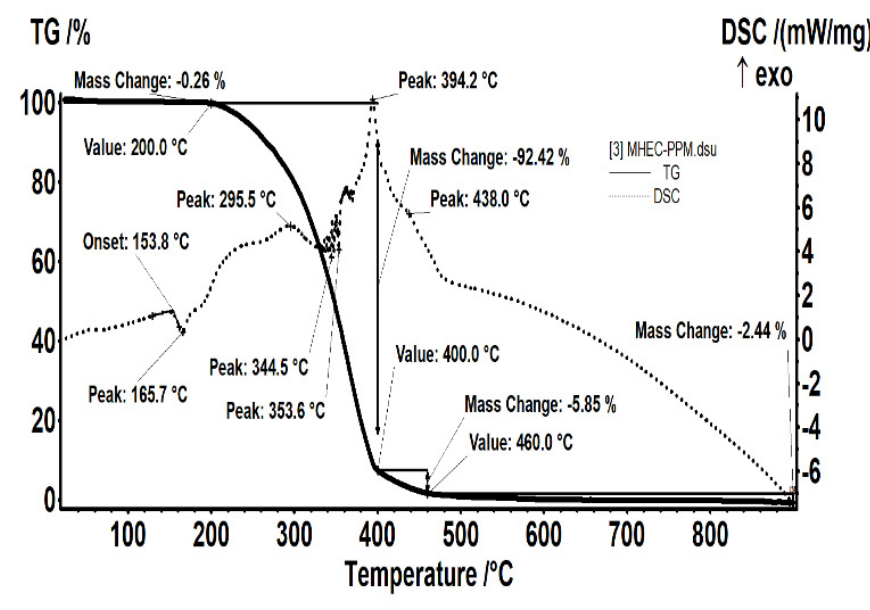

\section{TG $1 \%$}

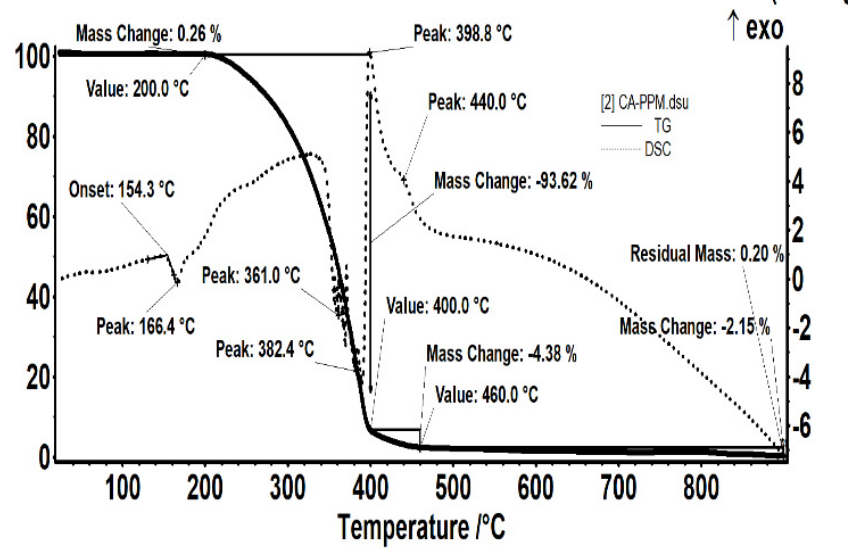

(b)

\section{TG $1 \%$}

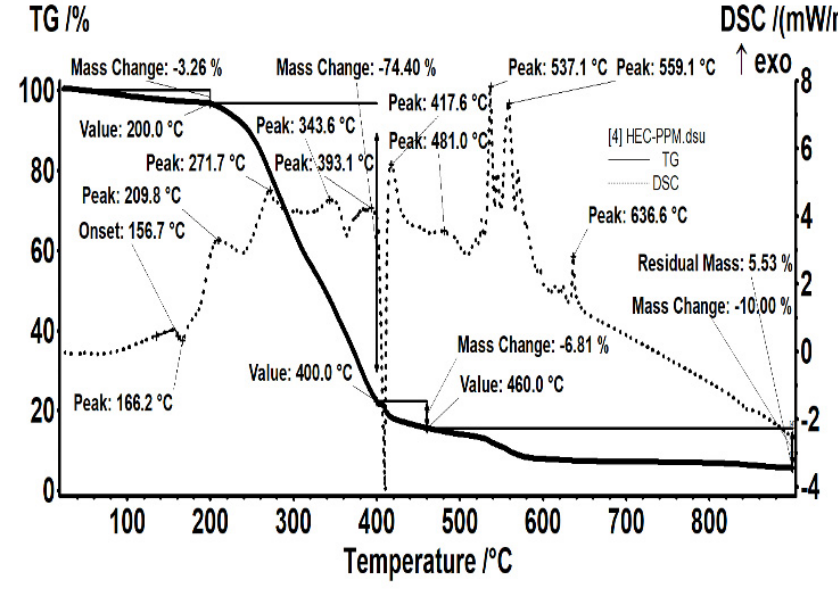

(d)

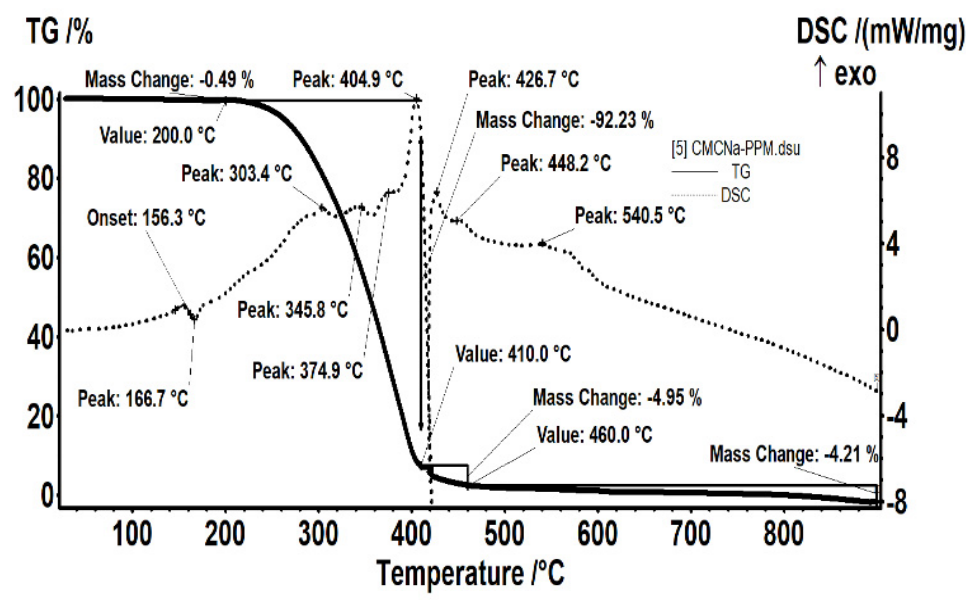

(e)

Figure 6. Thermal diagrams for hollow fiber membranes: (a) PPM; (b) CA-PPM; (c) MHEC-PPM; (d) HEC-PPM; (e) NaCMC-PPM.

The sample CA-PPM (Figure $6 \mathrm{~b}$ ) is stable up to $200^{\circ} \mathrm{C}$, the recorded mass loss being $0.26 \%$. At the same time, a small endothermic effect is present on the DSC curve, with onset at $154.3^{\circ} \mathrm{C}$ and a peak at $166.4{ }^{\circ} \mathrm{C}$. This effect corresponds to the melting of the polypropy- 
lene. Between 200 and $400{ }^{\circ} \mathrm{C}$ the sample presents a mass loss of $93.62 \%$. The effects on DSC curve starts with an exothermic, broad one, with peaks at 240 and $327.5^{\circ} \mathrm{C}$, followed by a series of endothermic peaks. This indicates that first process is an oxidation of the polymeric fiber, followed by a series of decompositions. The carbonaceous mass obtained towards end decomposition starts to burn and a strong, sharp exothermic peak can be observed at $398.8^{\circ} \mathrm{C}$. The final oxidation process takes place quick up to $460{ }^{\circ} \mathrm{C}$, with a recorded mass loss of $4.38 \%$, and proceeds slowly after, with another $2.15 \%$ mass loss up to $900{ }^{\circ} \mathrm{C}$.

The sample MHEC-PPM (Figure 6c) is stable up to $200{ }^{\circ} \mathrm{C}$, the recorded mass loss being $0.26 \%$. At the same time, a small endothermic effect is present on the DSC curve, with onset at $153.8^{\circ} \mathrm{C}$ and a peak at $165.7^{\circ} \mathrm{C}$. This effect corresponds to the melting of the polypropylene. Between 200 and $400{ }^{\circ} \mathrm{C}$ the sample presents a mass loss of $92.42 \%$. The first effect on DSC curve is exothermic, broad, asymmetric, with peaks at 235 and $295.5^{\circ} \mathrm{C}$, and indicates that some oxidation processes are responsible for the mass lost in the first part. There are multiple endothermic effects around $350{ }^{\circ} \mathrm{C}$, which indicate the predominance of decomposition processes. The carbonaceous mass obtained by the end of the decomposition starts to burn and a strong, sharp exothermic peak can be observed at $394.2^{\circ} \mathrm{C}$. The final oxidation process takes place quickly up to $460{ }^{\circ} \mathrm{C}$, with a recorded mass loss of $5.85 \%$, and proceeds slowly after, with another $2.44 \%$ mass loss up to $900{ }^{\circ} \mathrm{C}$.

The sample HEC-PPM (Figure $6 \mathrm{~d}$ ) is losing $3.26 \%$ of its initial mass up to $200{ }^{\circ} \mathrm{C}$, indicating the presence of a small HEC quantity on fiber surface. In the same time, a small endothermic effect is present on the DSC curve, with onset at $156.7^{\circ} \mathrm{C}$ and a peak at $166.2^{\circ} \mathrm{C}$. This effect corresponds to the melting of the polypropylene. Between 200 and $400{ }^{\circ} \mathrm{C}$ the sample exhibit a mass loss of $74.40 \%$. The effects on DSC curve starts with a series of exothermic peaks at $209.8,271.7,343.6$ and $393.1{ }^{\circ} \mathrm{C}$ and $327.5{ }^{\circ} \mathrm{C}$ indicating the presence of multiple degradative-oxidative processes. The carbonaceous mass obtained towards end decomposition starts to burn and a series of strong, sharp exothermic peaks can be observed at $417.6,537.1$ and $559.1{ }^{\circ} \mathrm{C}$. In the final oxidation process, up to $600{ }^{\circ} \mathrm{C}$, a mass loss of $10.00 \%$ is recorded.

The sample NaCMC-PPM (Figure 6e) is stable up to $200{ }^{\circ} \mathrm{C}$, the recorded mass loss being $0.49 \%$. A small endothermic effect is present on the DSC curve, with onset at $156.3^{\circ} \mathrm{C}$ and a peak at $166.7^{\circ} \mathrm{C}$. This effect corresponds to the melting of the polypropylene fibers. Between 200 and $410{ }^{\circ} \mathrm{C}$ the sample presents a mass loss of $92.23 \%$. The associated effects on DSC curve are exothermic, overlapped, with peaks at 303.4, 345.8, 374.9 and $404.9{ }^{\circ} \mathrm{C}$, indicating the occurring of oxidation processes in this interval. The carbonaceous mass obtained starts to burn after $410^{\circ} \mathrm{C}$, when some strong, sharp exothermic peaks can be observed at 426.7 and $448.2^{\circ} \mathrm{C}$. In the final oxidation process the sample is losing $4.21 \%$ up to $900{ }^{\circ} \mathrm{C}$.

Table 5. Main thermal characteristics of the hollow fiber membranes.

\begin{tabular}{|c|c|c|c|c|}
\hline Sample & $\begin{array}{l}\text { PP Melting } \\
\text { Onset }\left({ }^{\circ} \mathrm{C}\right)\end{array}$ & $\begin{array}{l}\text { PP Melting Peak } \\
\left({ }^{\circ} \mathrm{C}\right)\end{array}$ & $\begin{array}{c}\text { Decomposition Start } \\
\left({ }^{\circ} \mathrm{C}\right)\end{array}$ & $\begin{array}{c}\mathrm{T}_{10 \%} \\
\text { (Temperature for } 10 \% \\
\text { Mass Loss) }\left({ }^{\circ} \mathrm{C}\right)\end{array}$ \\
\hline 1_PP_fiber (support) & 154.9 & 165.0 & 180 & 258 \\
\hline 2 CA-PPM & 154.3 & 166.4 & 200 & 274 \\
\hline 3 MHEC-PРM & 153.8 & 165.7 & 200 & 266 \\
\hline 4 HEC-PPM & 156.7 & 166.2 & 80 & 246 \\
\hline 5 NaCMC-PPM & 156.3 & 166.7 & 200 & 281 \\
\hline
\end{tabular}

\subsubsection{Chemical Structure and Composition}

The chemical structure of the chosen cellulosic derivatives was highlighted through Fourier transform infrared spectroscopy (FT-IR), in which the functional groups that can 
interact specifically with the amino acids considered are observed (Figure 7 and Figure S3 and Table 6) Their characterization was obtained directly onto the solid samples, using the Bruker Tensor 27 with ATR diamond for the materials in this study.

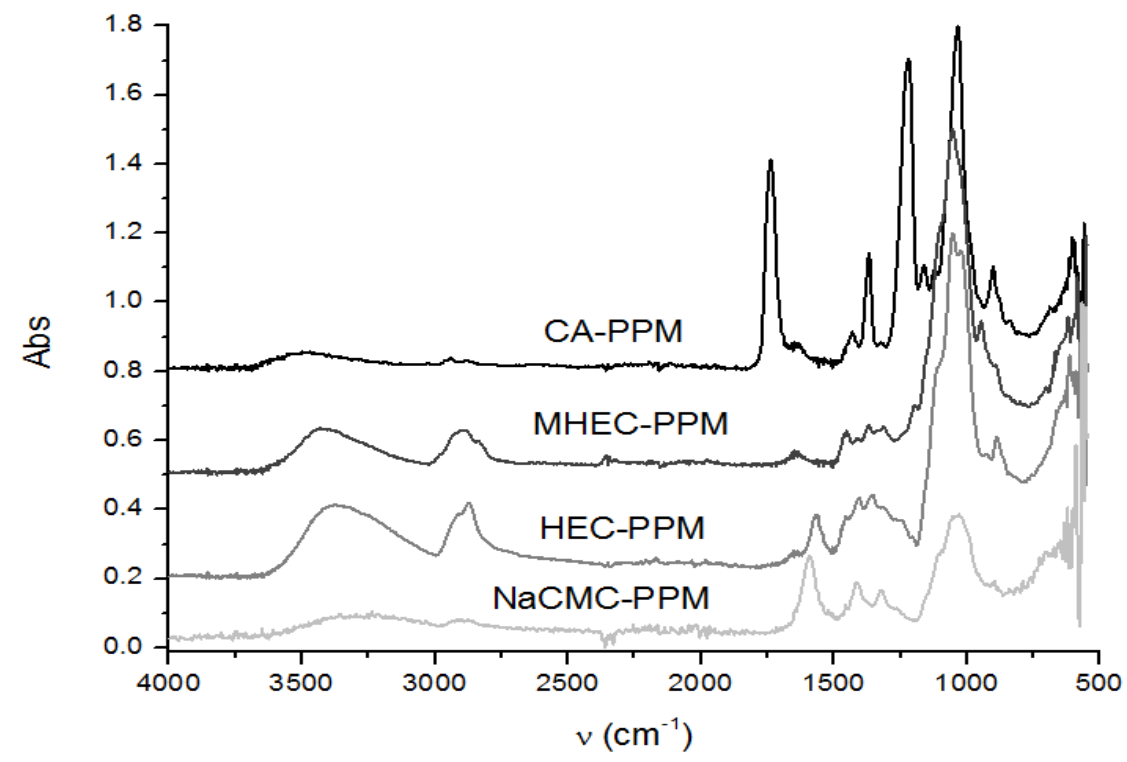

Figure 7. The Fourier transform infrared spectroscopy (FT-IR) spectrum of the impregnated membranes.

Table 6. The main structural characteristics identified through Fourier transform infrared spectroscopy (FT-IR).

\begin{tabular}{|c|c|c|c|c|c|c|}
\hline \multirow{2}{*}{$\begin{array}{l}\text { Cellulose } \\
\text { Derivatives }\end{array}$} & \multicolumn{6}{|c|}{$\begin{array}{l}\text { Wave Numbers of the Interesting Groups for the Considered } \\
\text { Interactions }\left(\mathrm{cm}^{-1)}\right.\end{array}$} \\
\hline & $\begin{array}{l}v \mathrm{O}-\mathrm{C}- \\
\delta \mathrm{O}-\mathrm{C}-\mathrm{O}\end{array}$ & $\begin{array}{l}\delta-\mathrm{CH}_{2} \\
\delta \mathrm{O}-\mathrm{H}\end{array}$ & $\delta-\mathrm{CH}_{2}$ & $v \mathrm{C}=\mathrm{O}$ & $v \mathrm{C}-\mathrm{H}$ & $v \mathrm{O}-\mathrm{H}$ \\
\hline CA & 1034 & 1371 & 1410 & 1743 & $2960 \mathrm{~s}$ & 3499 \\
\hline HEC & 1057 & 1352 & 1412 & - & 2987 & 3374 \\
\hline MHEC & 1055 & 1371 & 1420 & - & 2896 & 3422 \\
\hline $\mathrm{NaCMC}$ & 1034 & 1319 & 1418 & - & 2940 & 3280 \\
\hline
\end{tabular}

$v=$ vibration; $\delta$ = deformation.

The chemical structure of the four cellulosic derivatives which impregnate the membranes indicates possibilities of interaction with the amino acids or their ionic forms, both by hydrogen or dipole-dipole bonds (given by the carboxyl or amino groups) and by hydrophobic interactions of hydrocarbon chains. This statement is strengthened by the character of the radical $\mathrm{R}$ (Figure 1a) of the considered amino acids: aromatic hydrophobic (phenylalanine) or aliphatic hydrophobic (alanine and methionine).

Of course, depending on the $\mathrm{pH}$ of operation in the separation with the considered membranes, the complexity of the amino acid-cellulose derivative interaction must be taken into account. The superficial composition determined through energy dispersive spectroscopy analysis (EDAX) of impregnated membranes Cell-D-PPM compared with the PPM support membrane shows the appearance in different concentrations of oxygen atoms on the surface (Table 7 and Supplementary Figure S4).

This concentration of the oxygen atoms on the surface of the membrane will be responsible for the attraction of the amino acid, but the migration inside the impregnated membrane depends on the overall composition of the cellulose derivative used for impregnation. 
Table 7. The surface composition of the prepared impregnated membranes.

\begin{tabular}{|c|c|c|c|c|c|c|c|c|c|c|}
\hline \multirow{2}{*}{$\begin{array}{l}\text { Membranes/ } \\
\text { Composition }\end{array}$} & \multicolumn{2}{|c|}{ PPM } & \multicolumn{2}{|c|}{ CA-PPM } & \multicolumn{2}{|c|}{ HEC-PPM } & \multicolumn{2}{|c|}{ MHEC-PРM } & \multicolumn{2}{|c|}{ NaCMC-PPM } \\
\hline & Weight $\%$ & Atomic\% & Weight $\%$ & Atomic\% & Weight $\%$ & Atomic\% & Weight $\%$ & Atomic\% & Weight $\%$ & Atomic\% \\
\hline $\mathrm{CK}$ & 93.49 & 95.03 & 68.90 & 77.87 & 88.26 & 90.92 & 53.74 & 60.74 & 87.86 & 90.79 \\
\hline $\mathrm{OK}$ & 6.51 & 4.97 & 31.10 & 28.23 & 11.74 & 9.08 & 46.26 & 39.26 & 11.27 & 8.74 \\
\hline $\mathrm{Na} \mathrm{K}$ & - & - & - & - & - & - & - & - & 0.88 & 0.47 \\
\hline
\end{tabular}

\subsubsection{Membrane Morphology}

The surface morphology of the considered samples was analyzed using a scanning electron microscope (SEM), high-resolution scanning electron microscope (HR-SEM). All samples were properly dried prior to the microscopy analysis and were sufficiently coated with a sputtered gold layer of $400 \AA$.

The results of the image analysis are presented in Figures 8-11 (see Supplementary Figures S5-S8).

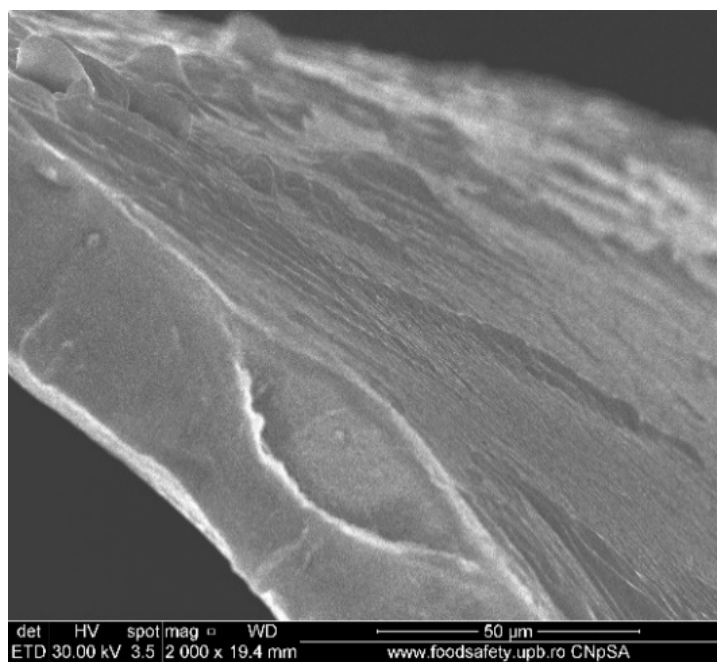

(a)

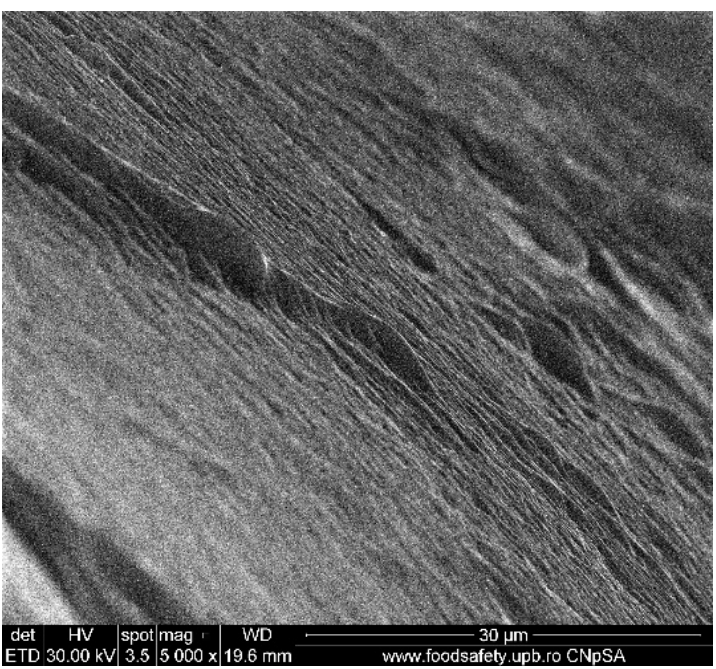

(b)

Figure 8. Morphology CA-PPM membranes: (a) membrane cross-section; (b) membrane surface.

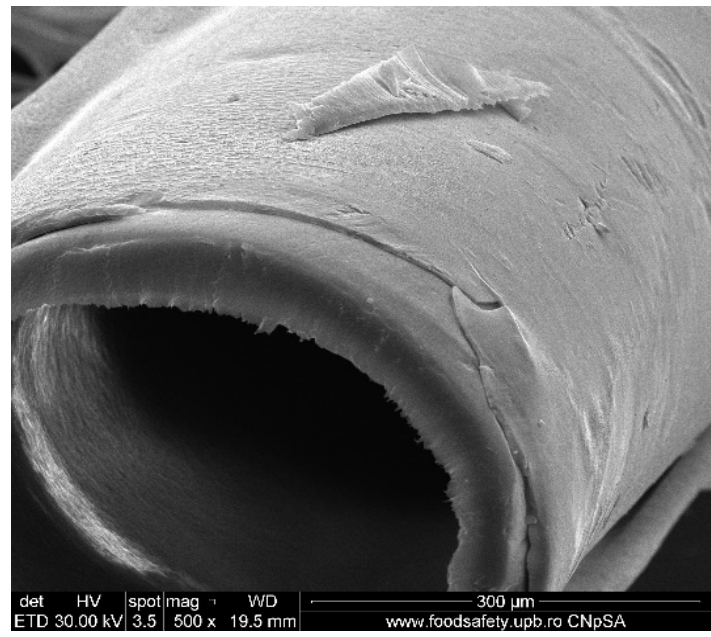

(a)

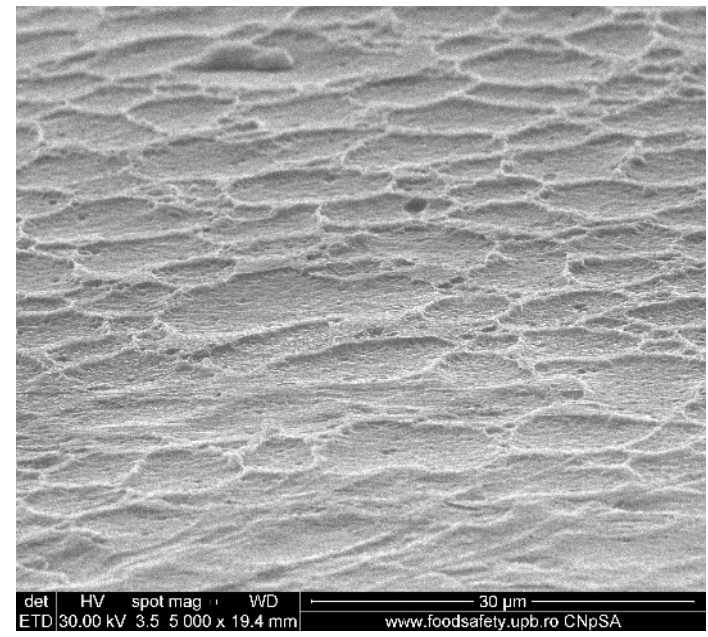

(b)

Figure 9. Morphology HEC-PPM membranes: (a) membrane cross-section; (b) membrane surface. 


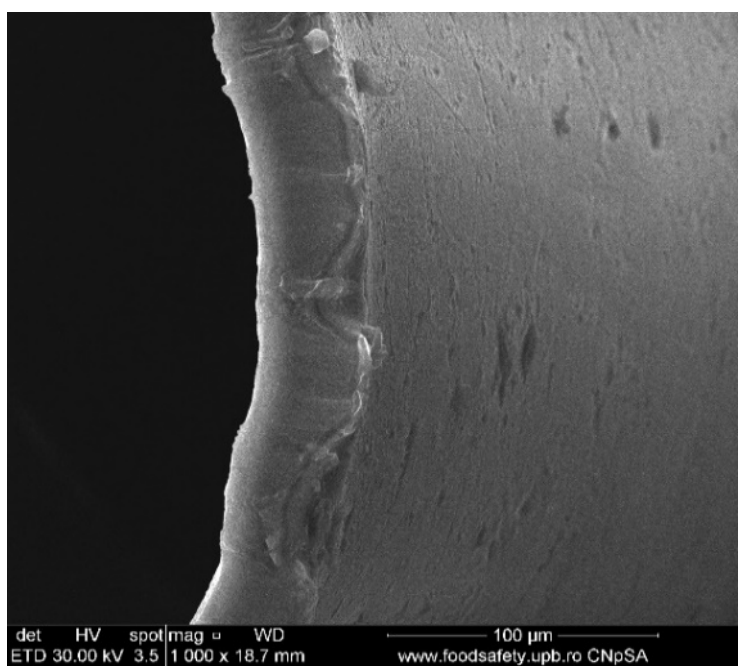

(a)

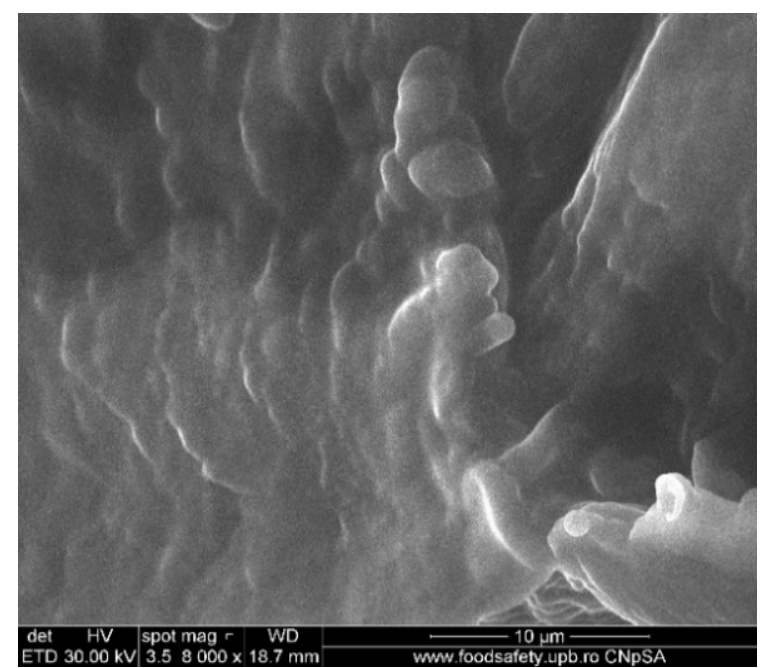

(b)

Figure 10. Morphology MHEC-PPM membrane: (a) membrane cross-section; (b) membrane surface.

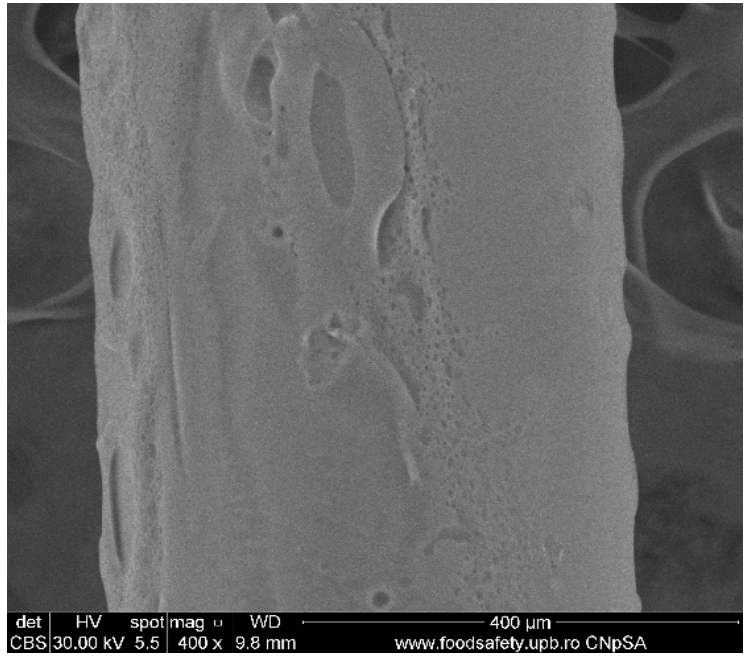

(a)

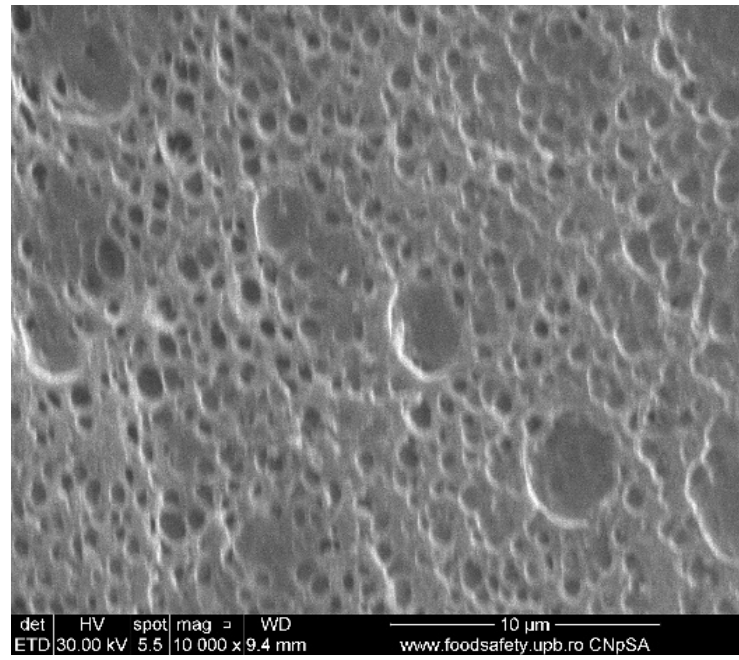

(b)

Figure 11. Morphology NaCMC-PPM membranes: (a) view; (b) membrane surface.

From the images obtained through scanning electron microscopy (SEM) and high resolution scanning electron microscopy (HR-SEM) some common features of the obtained impregnated membranes can be highlighted, but also several specificities, as follows:

- Impregnation of the membranes takes place superficially and adherently, without the cellulosic derivative reaching the inside of propylene hollow fiber membrane (Figures 8a, 9a and 10a).

- The layer of cellulosic derivative from the surface of the membranes has about $5 \mu \mathrm{m}$ (Supplementary Figures S5-S8a,b) being highlighted in the detail depicted in Figure 12. 


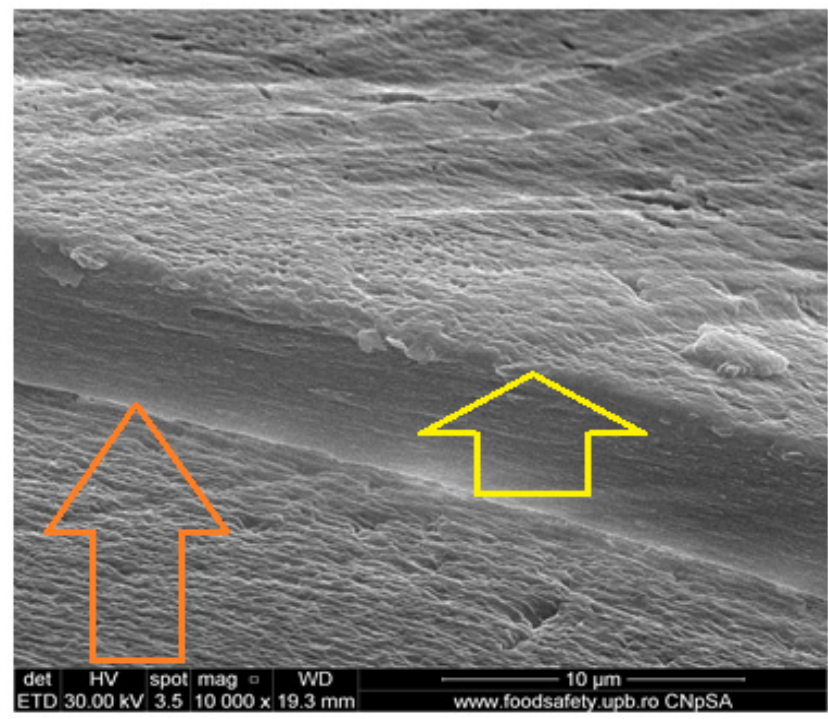

support

\section{superficial layer}

Figure 12. Detail of the superficial layer from the cellulose derivatives on the polypropylene hollow fiber.

- The surface layer of cellulosic derivative has a microstructure specific to nanofiltration membranes (Figures $8 \mathrm{~b}, 9 \mathrm{~b}, 10 \mathrm{~b}$ and $11 \mathrm{~b}$ ), highlighted in two significant details in Figure 13.

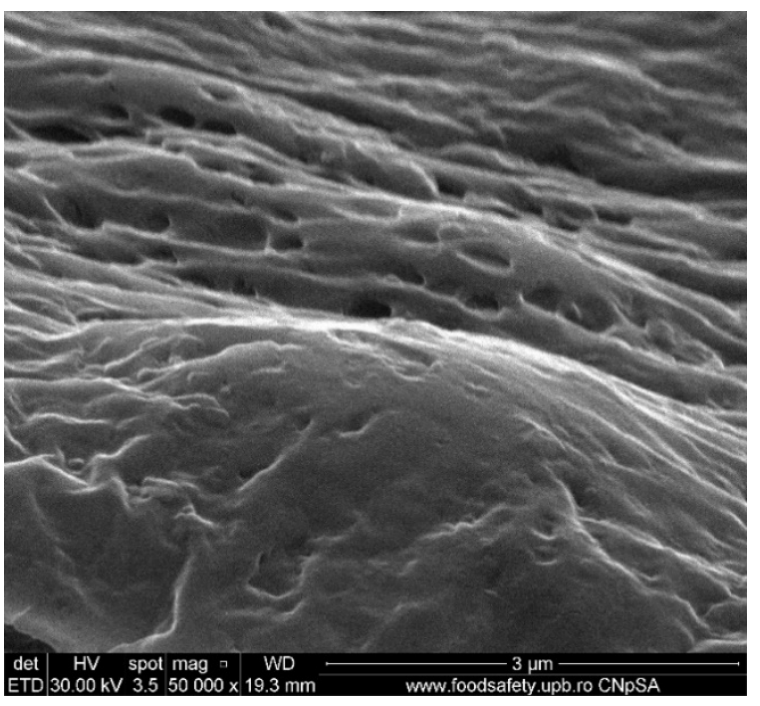

(a)

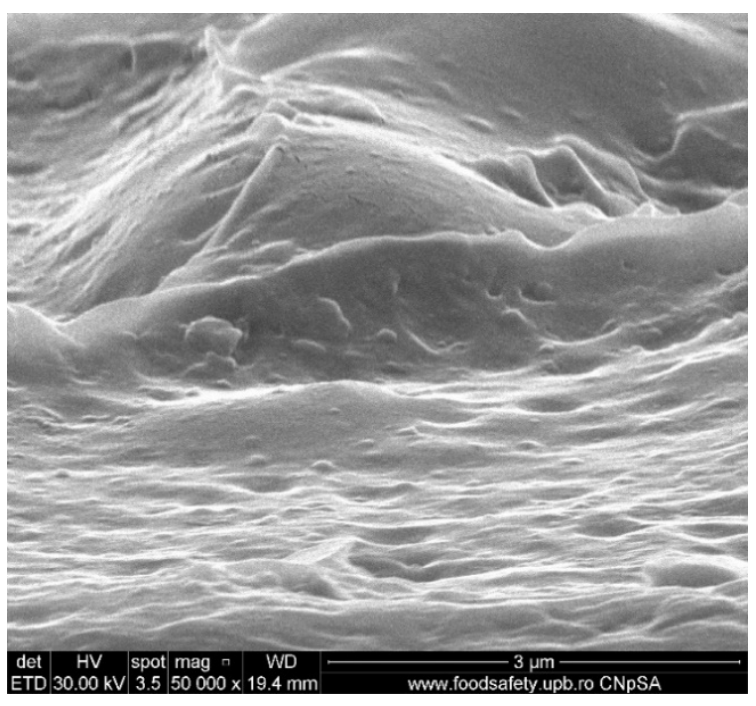

(b)

Figure 13. Detail of the superficial layer from the cellulose derivatives: (a) cellulose acetate and (b) 2-hydroxyethyl cellulose.

\subsection{Performance of the Amino Acids Removal Process}

The separation of amino acids is very important, and the use of membranes based on functionalized biopolymers involves the careful study of working parameters and especially of operational ones, such as $\mathrm{pH}$ and temperature. That is why the main operating parameters and their influence on the evolution of the target chemistry species separation are presented.

The $\mathrm{pH}$ of the feeding solution was equal to 2 and 12, respectively, to have the certainty of the formation of the carboxyl anion, in the first case and of the ammonium cation, in the 
second case (Figure $1 \mathrm{~b}$ and Table 3$)$. The receiving phase consists of pure water $(\mathrm{pH}=7)$ so that when re-extracted from the membrane the amino acid reaches the shape specific to the isoelectric point (Figure 14). The working temperature was $25^{\circ} \mathrm{C}$ in the whole membrane system.

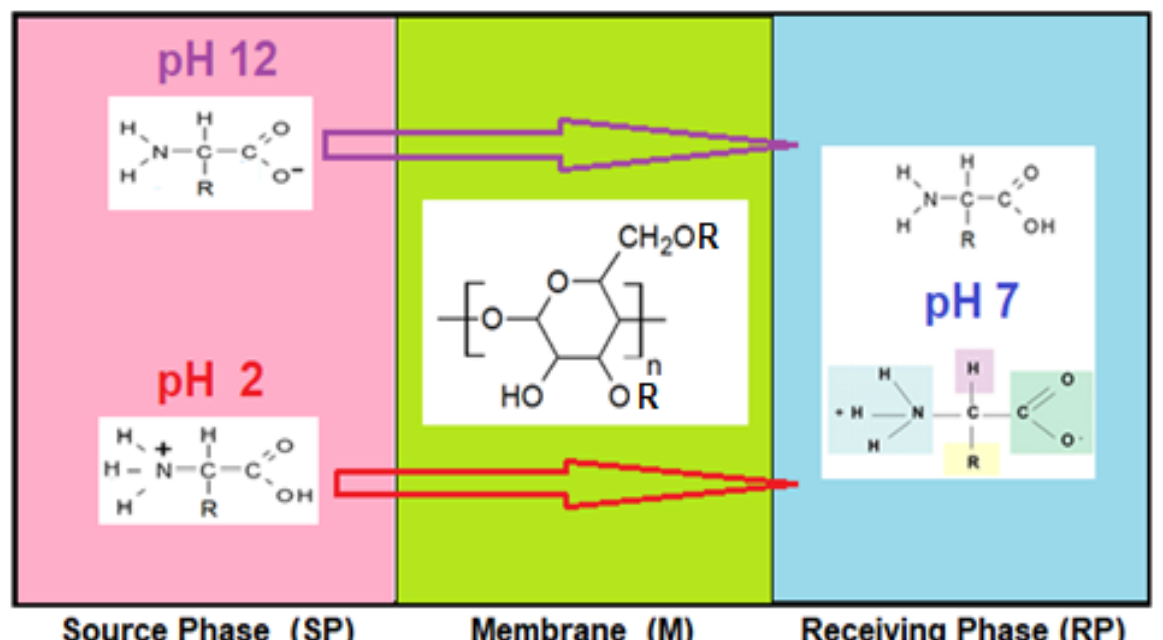

(a)

(b)

Figure 14. The transport mechanism of the amino acids at: (a) $\mathrm{pH}=2$ and $\mathrm{pH}=12$ for the source phase (SP); and (b) $\mathrm{pH}=7$ (pure water) in the receiving phase (RP).

3.2.1. The Effect of the Composition of the Impregnated Membrane on the Recovery of Amino Acids

The first pertraction tests of the chosen amino acids, alanine, phenylalanine and methionine, considered the study of the evolution of amino acids in source phase, in a determined interval of $120 \mathrm{~min}$ (Figures 15 and 16).

The concentration of the three amino acids decreases rapidly in the first $60 \mathrm{~min}$ of operation, after which the decrease is slower, or a level is created (Figures 15 and 16). The lowest decrease rate is in all cases for alanine, followed by methionine, and phenylalanine. However, some peculiarities stood out:

- The difference in transfer rate was large between alanine and the other two amino acids, especially for HEC-PPM, MHEC-PPM and NaCMC-PPM membranes, at $\mathrm{pH}=12$ and for CA-PPM and MHEC-PPM membranes, at $\mathrm{pH}=2$,

- The transfer rates differed less in the case of CA-PPM at $\mathrm{pH}=12$ and for HEC-PPM and $\mathrm{NaCMC}$ at $\mathrm{pH}=2$.

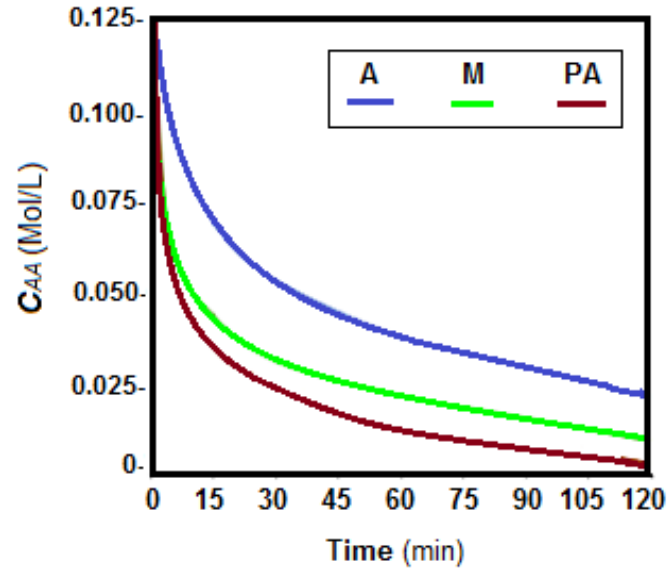

(a)

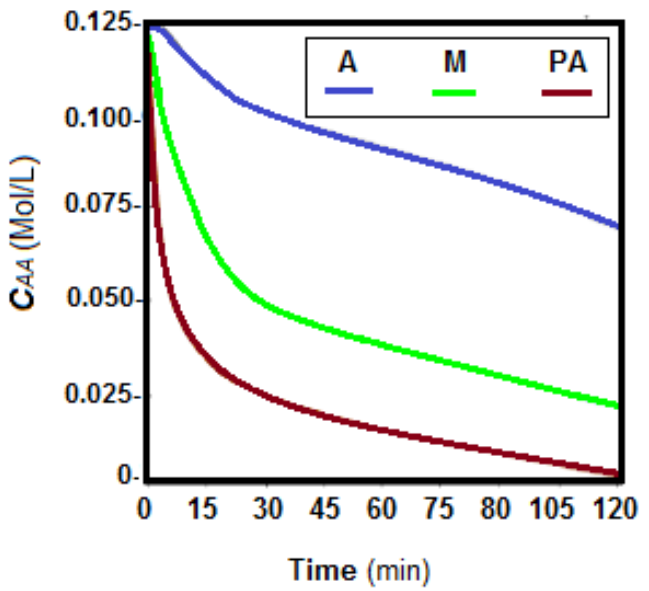

(b)

Figure 15. Cont. 


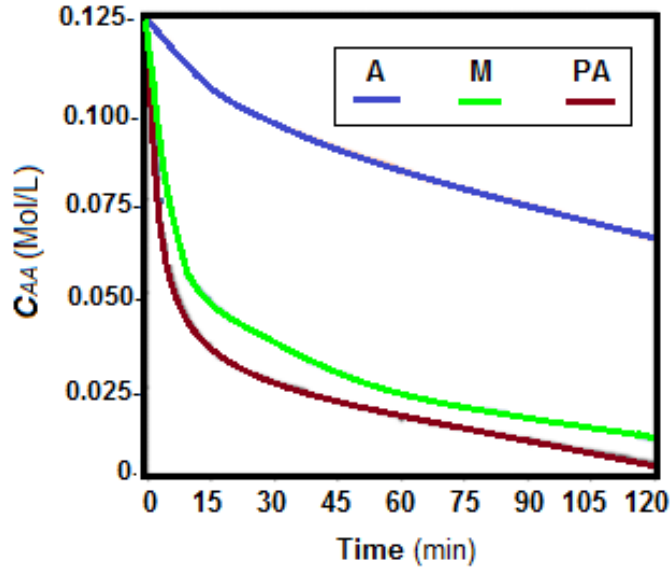

(c)

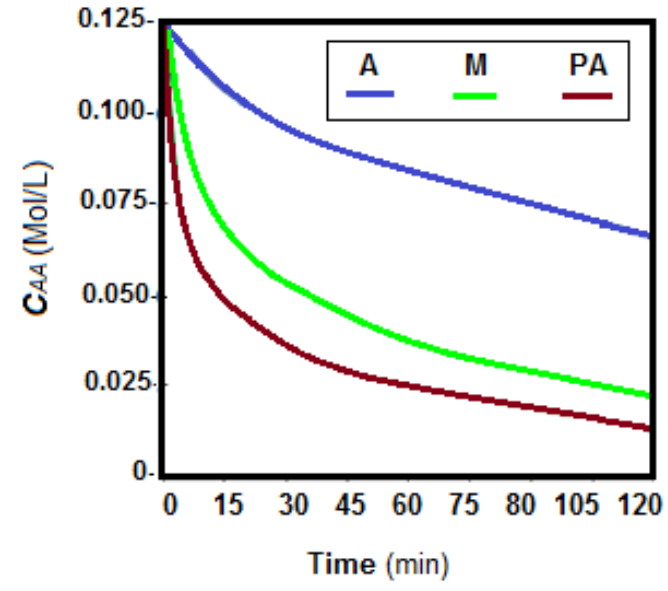

(d)

Figure 15. Variation of source phase amino acid concentration depending on the operating time at $\mathrm{pH} \mathrm{SP}_{\mathrm{SP}}=12$ and $\mathrm{pH} \mathrm{RP}_{\mathrm{R}}=7:(\mathbf{a})$ CA-PPM; (b) HEC-PPM; (c) MHEC-PPM; (d) NaCMC-PPM. A = alanine (blue); $\mathbf{M}=$ methionine (green) and PA = phenylalanine (brown).

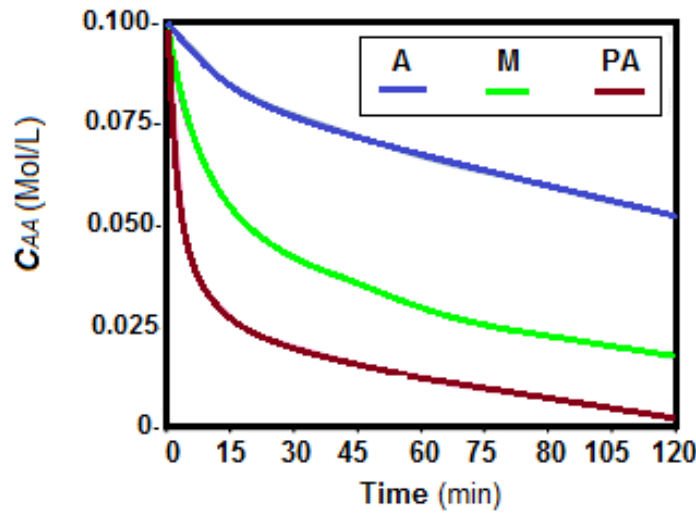

(a)

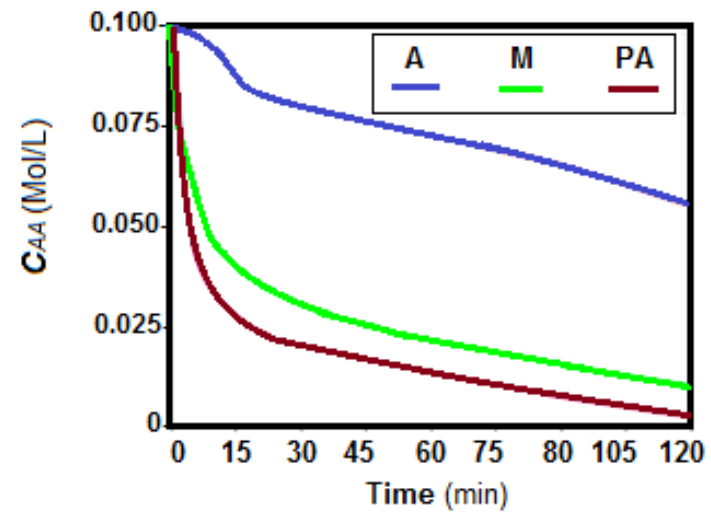

(c)

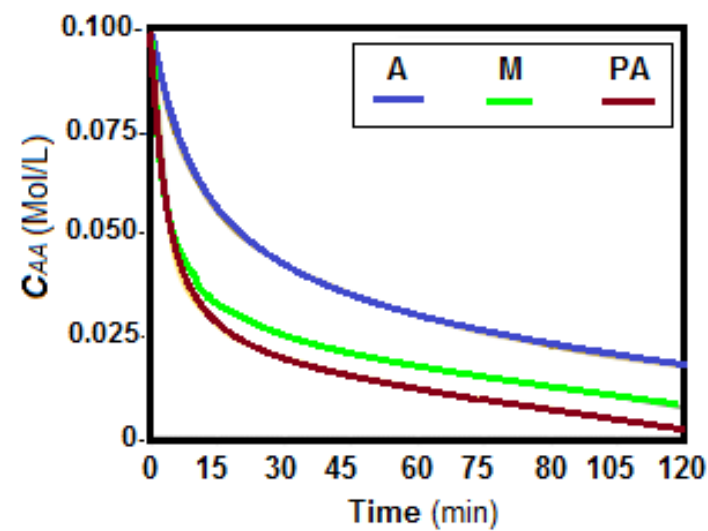

(b)

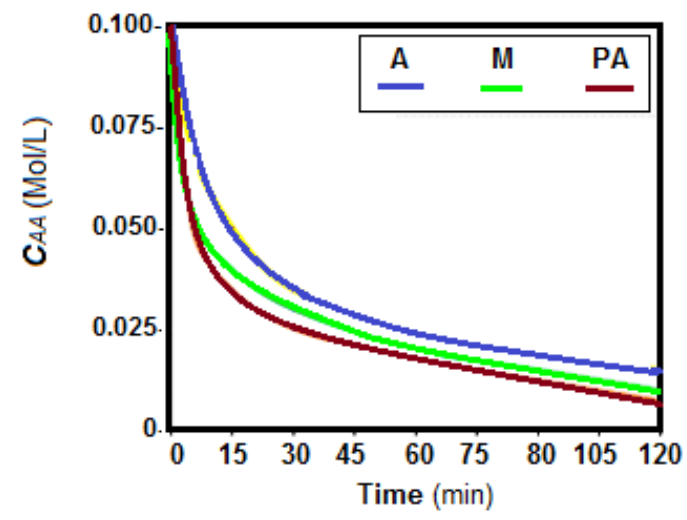

(d)

Figure 16. Variation of source phase amino acid concentration depending on the operating time at $\mathrm{pH} \mathrm{SP}_{\mathrm{SP}}=2$ and $\mathrm{pH} \mathrm{RP}_{\mathrm{R}}=7$ : (a) CA-PPM; (b) HEC-PPM; (c) MHEC-PPM; and (d) NaCMC-PPM. A = alanine (blue); $\mathbf{M}=$ methionine (green), and PA = phenylalanine (brown).

Considering the amino acid flows (Table 8), depending on the nature of cellulose derivative that forms the impregnated membrane and the surface composition (Table 7), it can be seen that there were significant differences in the flow of the three amino acids. 
Table 8. The fluxes of the cellulose derivatives membranes at $\mathrm{pH}=2$ and $\mathrm{pH}=12$ of the source phase $(\mathbf{A}=$ alanine; $\mathbf{M}=$ methionine, and $\mathbf{P A}=$ phenylalanine).

\begin{tabular}{|c|c|c|c|c|c|c|c|c|c|c|c|c|}
\hline \multirow{3}{*}{$\begin{array}{c}\text { pH Source } \\
\text { Phase }\end{array}$} & \multicolumn{12}{|c|}{ Membrane Flux $\left(\mu \mathrm{Mol} / \mathrm{m}^{2} \cdot \mathrm{s}\right)$} \\
\hline & \multicolumn{3}{|c|}{ CA-PPM } & \multicolumn{3}{|c|}{ HEC-PPM } & \multicolumn{3}{|c|}{ MHEC-PPM } & \multicolumn{3}{|c|}{ NaCMC-PPM } \\
\hline & A & $\mathbf{M}$ & PA & A & $\mathbf{M}$ & PA & A & $\mathbf{M}$ & PA & A & $\mathbf{M}$ & PA \\
\hline 2 & 83.3 & 186.1 & 241.6 & 180.5 & 222.5 & 244.5 & 69.4 & 208.5 & 227.8 & 194.4 & 229.0 & 230.8 \\
\hline 12 & 236.1 & 277.0 & 300.4 & 83.2 & 235.6 & 305.4 & 111.4 & 280.5 & 305.5 & 97.2 & 236.1 & 278.0 \\
\hline
\end{tabular}

The results obtained show that phenylalanine has the highest fluxes through all four types of membranes, followed by methionine and alanine. $\mathrm{pH}$ does not change this order but suggests the possibility of selective separation of the three amino acids, more obvious being the separation of alanine from phenylalanine.

Of the four kinds of membrane, the most suitable for recuperative separation of the considered amino acids are those based on cellulose acetate and methyl 2-hydroxyethylcellulose.

3.2.2. The Effect of $\mathrm{pH}$ and Solubility of Amino Acids on the Flow through Impregnated Membranes

The flow performances were also found in the efficiency of phenylalanine extraction, chosen for the highest transfer rates found in all previous experiments for all four types of membrane (Figure 17). Depending on the $\mathrm{pH}$ of the source phase, the following succession was obtained:

$$
E E_{p H 12}=E E_{p H 2}>E E_{p H 7}
$$

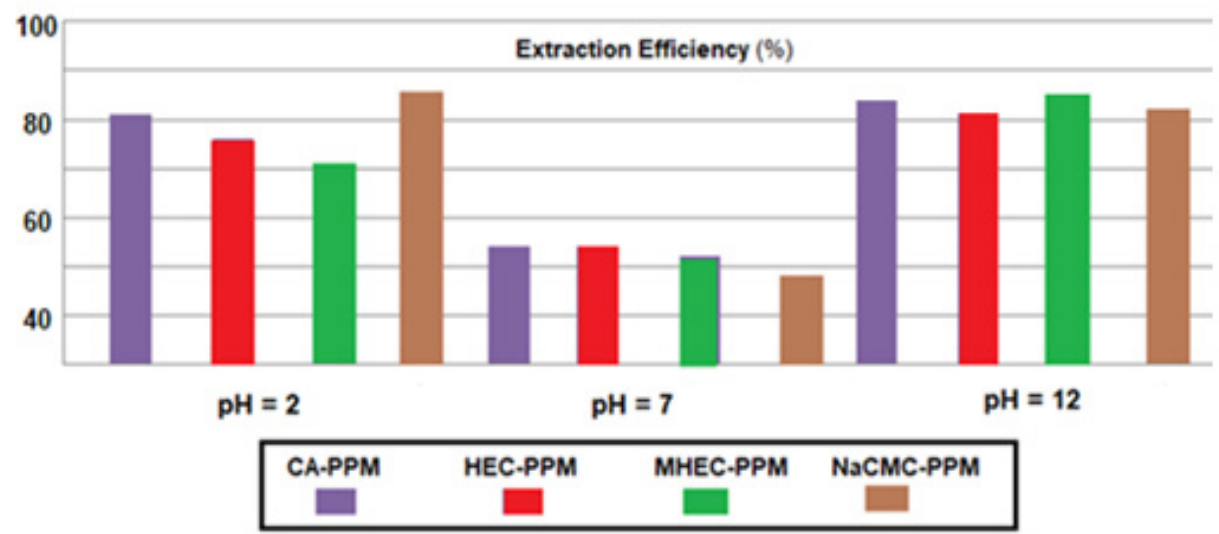

Figure 17. The phenylalanine extraction efficiency EE (\%) variation versus the $\mathrm{pH}$ of the source phase (SP) for the prepared membranes.

Determination of the efficiency of extraction of the amino acids from source solutions of $\mathrm{pH}=12$, at temperatures of 35,45 and $55^{\circ} \mathrm{C}$, shows that the separation efficiency grows with increasing temperature for all four types of membranes (Figure 18). A more pronounced effect can be seen in the case of HEC-PPM and NaCMC-PPM membranes, which could correlate with higher hydrophilicity of membranes based on the two cellulosic derivatives. However, the usage of these impregnation derivatives is limited by the solubility of the polymeric layer in the source solution, which would lead over time to significant losses and drastic decreases in membrane thickness, known in the literature of the membranes as 'membrane washing' [77]. 

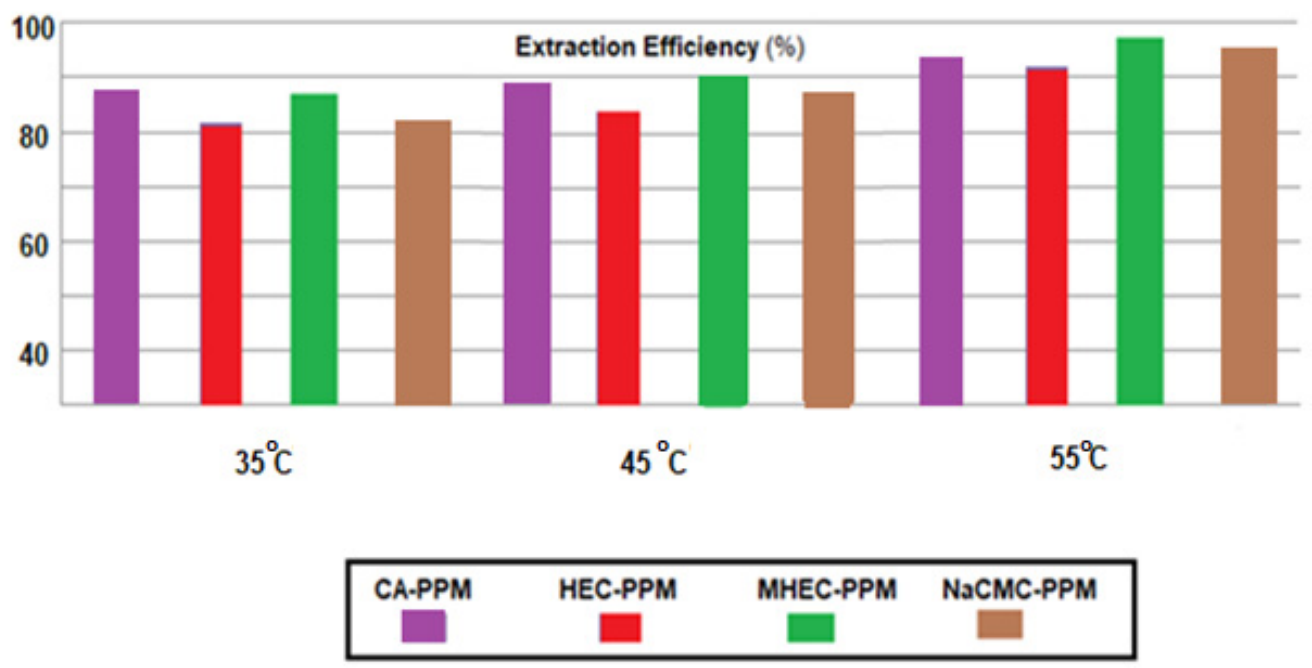

Figure 18. The phenylalanine extraction efficiency EE (\%) variation versus the temperature of source phase (SP) for the prepared membranes.

The transfer rate of alanine is lower in all cases, remaining in high concentration in the source phase. This observation suggests the possibility of separating the three chosen amino acids by the appropriate choice of the cellulosic derivative. Thus, phenylalanine and methionine can be recovered from the receiving phase and alanine is concentrated in the source phase.

One explanation that would answer to the results presented in Figures 13, 14 and 15a would be that the solubility of alanine is much higher than that of the other two amino acids (Table 3), which would lead to an important retention of it in the source phase.

The argument presented is even more valid as the transfer of phenylalanine is in all cases higher than that of methionine. Thus, it could be generalized that that the transfer flow $(J)$ of amino acids through the studied membranes grows in this order:

$$
J_{\text {phenylalanine }}>J_{\text {methionine }}>J_{\text {alanine }}
$$

which would thus be correlated with the solubility in pure water (So) of the amino acids:

$$
\text { So } \boldsymbol{o}_{\text {phenylalanine }}<\text { So }_{\text {methionine }}<\text { So } \boldsymbol{o}_{\text {alanine }}
$$

The results can be explained by the fact that in aqueous solution the amino acids participate in proton exchange equilibria which are controlled by $\mathrm{pH}$ :

$$
\begin{gathered}
\mathrm{HOOC}-\mathrm{CHR}-\mathrm{NH}_{2}+\mathrm{H}_{3} \mathrm{O}^{+} \leftrightarrow \mathrm{HOOC}^{-C H R}-\mathrm{NH}_{3}{ }^{+}+\mathrm{HOH} \\
\mathrm{HOOC}-\mathrm{CHR}-\mathrm{NH}_{2}+\mathrm{HOH} \leftrightarrow{ }^{-} \text {OOC-CHR-NH}{ }_{2}+\mathrm{H}_{3} \mathrm{O}^{+}
\end{gathered}
$$

Based on these balances, the acidity constants are defined:

$$
\begin{aligned}
K_{a_{1}} & =\frac{\left[\mathrm{HOOC}-\mathrm{CHR}-\mathrm{NH}_{2}\right]\left[\mathrm{H}_{3} \mathrm{O}^{+}\right]}{\left[\mathrm{HOOC}-\mathrm{CHR}-\mathrm{NH}_{3}^{+}\right]} \\
K_{a_{2}} & =\frac{\left[\mathrm{OOC}-\mathrm{CHR}-\mathrm{NH}_{2}\right]\left[\mathrm{H}_{3} \mathrm{O}^{+}\right]}{\left[\mathrm{HOOC}-\mathrm{CHR}-\mathrm{NH}_{2}\right]}
\end{aligned}
$$

The degree of formation of these chemical species can be assessed with the following relationships:

$$
\alpha_{0}=\frac{1}{1+10^{p K_{a_{2}}-p H}+10^{p K_{a_{1}}+p K_{a_{2}}-2 p H}}
$$




$$
\begin{gathered}
\alpha_{1}=\frac{1}{1+10^{p K_{a_{1}}-p H}+10^{p H-p K_{a_{2}}}} \\
\alpha_{2}=\frac{1}{1+10^{p H-p K_{a_{1}}}+10^{2 p H-p K_{a_{1}}-p K_{a_{2}}}}
\end{gathered}
$$

In which $\alpha_{0}, \alpha_{1}$ and $\alpha_{2}$ represent, respectively, the degrees of formation of the species -OOC-CHR-NH ${ }_{2}$, HOOC-CHR- $\mathrm{NH}_{2}$ and HOOC-CHR- $\mathrm{NH}_{3}{ }^{+}$, in the aminophenol solution.

The actual solubility $(S)$ of the considered amino acid is a function of $\mathrm{pH}$ and the solubility in pure water $\left(S_{0}\right)$, which explains the behavior of the amino acid in the pertraction process:

$$
S=S_{0} \cdot f(\alpha)
$$

With these relations one can illustrate the speciation diagram for a generic amino acid with: $p K_{a 1}=2.30$ and $p K_{a 2}=9.20$ (Figure 19a):

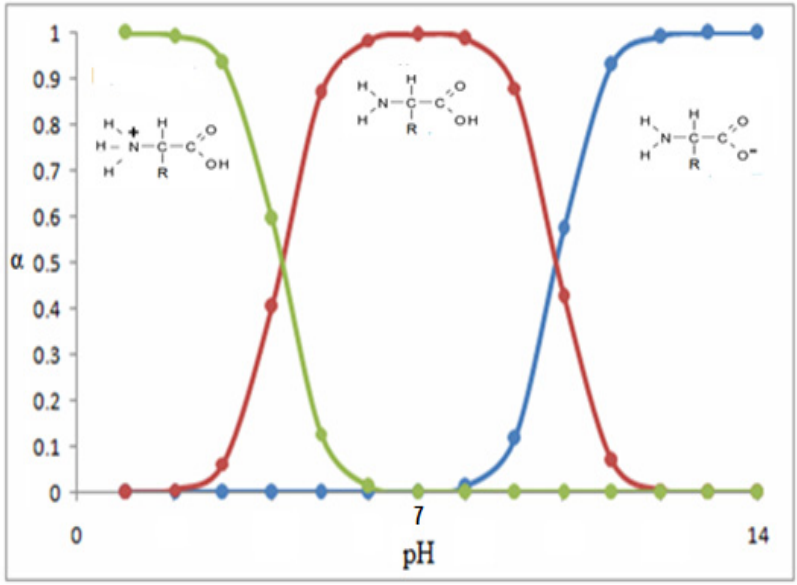

(a)

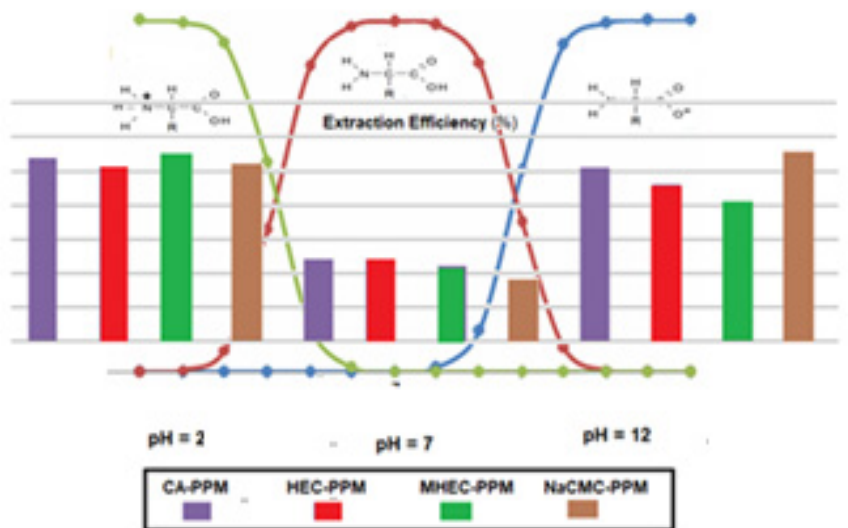

(b)

Figure 19. The speciation diagram of an amino acid, as a function on $\mathrm{pH}$ : (a) diagram; and (b) the diagrams superimposed over the extraction efficiency graph from Figure 17.

The results obtained in this paper are well illustrated by overlapping the diagram in Figure 17 with that of the chemical speciation of amino acids as function of $\mathrm{pH}$ (Figure 19a). Thus, it can be observed (Figure 19b) that if the $\mathrm{pH}$ of the source phase varies from 2 to 7 and then to 12 , while keeping constantly the $\mathrm{pH}$ of the receiving phase at 7 , then the extraction efficiency follows a winding curve that is specific to the existence of the three forms of the amino acid.

Based on the analysis of the speciation diagram, the $\mathrm{pH}$ conditions for the formation of the different chemical species of the studied amino acids can be anticipated, so as to obtain the optimal results in separation.

\section{Conclusions}

Amino acids are substances whose chemical and biochemical impact are quite remarkable. A special place in the study of the amino acids is occupied by their recovery from various sources, through a multitude of separation methods and techniques in which the membranes occupy a special place.

The present paper addressed the recuperative separation of three amino acids (alanine, phenylalanine and methionine) from synthetic solutions, using membranes from cellulose derivatives (cellulose acetate, 2-hydroxyethyl-cellulose and methyl 2-hydroxylethylcellulose or sodium carboxymethyl-cellulose) in the polypropylene hollow fiber matrix.

In order to determine the basic characteristics, the separation performances of the considered amino acids (retention, flow and selectivity) and the morphological and struc- 
tural ones, the membranes and membrane materials were analyzed by specific techniques: scanning electron microscopy (SEM), high resolution SEM (HR-SEM), Fourier transform infrared spectroscopy (FT-IR), energy dispersive spectroscopy (EDS) and thermal-gravimetric analyzer (TGA).

The support offered by polypropylene hollow fibers confers physical-chemical resistance, and cellulosic derivatives used for impregnation contribute to the separation performances of prepared impregnated membranes.

The results of the separation were influenced by the $\mathrm{pH}$ of the source phase and the solubility of the amino acids considered, the best results as flow and extraction efficiency being obtained when the source phase had a pronounced acidic or basic $\mathrm{pH}$ and the receiving phase had a neutral $\mathrm{pH}$ (pure water).

Among the amino acids, the highest transmembrane fluxes and extraction efficiency are offered by phenylalanine, then methionine and finally alanine. This succession is closely correlated with the solubility of the amino acids studied in water, a high solubility in water leading to a low transfer rate and separation efficiency.

By choosing the right cellulose derivative, phenylalanine and methionine can be recovered from the receiving phase, and alanine is concentrated in the source phase.

The considered cellulosic derivatives (cellulose acetate, 2-hydroxyethyl-cellulose, methyl 2-hydroxyethyl-cellulose or sodium carboxymethyl-cellulose) have a similar behavior in the separation process, but following the experiments, cellulose acetate and methyl 2-hydroxyethyl-cellulose are recommended for the realization of impregnated membranes. Although when increasing the operating temperature from 25 to $55^{\circ} \mathrm{C}$ the performance of membranes impregnated with 2-hydroxyethyl-cellulose and sodium carboxymethylcellulose increased, still the use of these membranes at high temperature raised the problem of degradation by the solubilization-washing phenomenon.

Supplementary Materials: The following are available online at https:/ /www.mdpi.com/article/10 $.3390 /$ membranes11060429/s1, Figure S1 and S2: The superposed thermal diagrams; Figure S3: FTIR spectra of the obtained membranes; Figure S4: The compositional surface (EDAX) of the support membrane and two impregnated membrane; Figures S5-S8: The results of the image analysis (SEM).

Author Contributions: Conceptualization, A.C.N., A.R.G., S.G.B. and G.N.; methodology, S.G.B., P.C.A., A.R.G., F.D. and A.C.N.; validation, G.N., O.O. and A.R.G.; formal analysis, A.P., I.A.D., D.P. and A.C.N.; investigation, A.C.N., G.N., S.G.B., O.O., F.D., D.P., P.C.A., I.A.D. and A.R.G.; resources, G.N., S.G.B. and A.R.G.; data curation, A.P., I.A.D.; writing-original draft preparation, A.C.N., G.N., S.G.B. and A.R.G.; writing-review and editing, A.R.G.; supervision, G.N., S.G.B. and A.C.N. All authors have read and agreed to the published version of the manuscript.

Funding: This research received no external funding.

Institutional Review Board Statement: Not applicable.

Informed Consent Statement: Not applicable.

Data Availability Statement: Not applicable.

Acknowledgments: The authors gratefully acknowledge the valuable help and friendly assistance of Eng. Roxana Truşcă for performing the scanning microscopy analysis.

Conflicts of Interest: The authors declare no conflict of interest.

\section{References}

1. Bolasco, P.; Caria, S.; Cupisti, A.; Secci, R.; Dioguardi, F.S. A novel amino acids oral supplementation in hemodialysis patients: A pilot study. Ren. Fail. 2011, 33, 1-5. [CrossRef]

2. Dabadé, D.S.; Jacxsens, L.; Miclotte, L.; Abatih, E.; Devlieghere, F.; De Meulenaer, B. Survey of multiple biogenic amines and correlation to microbiological quality and free amino acids in foods. Food Control. 2021, 120. [CrossRef]

3. Brancatelli, G.; Dalcanale, E.; Pinalli, R.; Geremia, S. Probing the structural determinants of amino acid recognition: X-ray studies of crystalline ditopic host-guest complexes of the positively charged amino acids, Arg, Lys, and His with a cavitand molecule. Molecules 2018, 23, 3368. [CrossRef] 
4. Martins, J.N.; Lima, J.C.; Basílio, N. Selective recognition of amino acids and peptides by small supramolecular receptors. Molecules 2020, 26, 106. [CrossRef] [PubMed]

5. Sandoval-Lira, J.; Mondragón-Solórzano, G.; Lugo-Fuentes, L.I.; Barroso-Flores, J. Accurate estimation of $\mathrm{pKb}$ values for amino groups from surface electrostatic potential (VS, $\mathrm{min})$ calculations: The isoelectric points of amino acids as a case study. J. Chem. Inf. Model. 2020, 60, 1445-1452. [CrossRef] [PubMed]

6. Sahraei, A.A.; Larachi, F. Chemical transformation and dissociation of amino acids on metal sulfide surface: Insights from DFT into the effect of surface vacancies on alanine-sphalerite system. Appl. Surf. Sci. 2021, 540, 148304. [CrossRef]

7. Cordes, M.; Koettgen, A.; Jasper, C.; Jacques, O.; Boudebous, H.; Giese, B. Influence of amino acid side chains on long-distance electron transfer in peptides: Electron hopping via "stepping stones." Angew. Chem. Int. Ed. 2008, 47, 3461-3463. [CrossRef]

8. Stückenschneider, K.; Merz, J.; Hanke, F.; Rozyczko, P.; Milman, V.; Schembecker, G. Amino-acid adsorption in MFI-type zeolites enabled by the pH-dependent ability to displace water. J. Phys. Chem. C 2013, 117, 18927-18935. [CrossRef]

9. Rimola, A.; Sodupe, M.; Ugliengo, P. Affinity scale for the interaction of amino acids with silica surfaces. J. Phys. Chem. C 2009, 113, 5741-5750. [CrossRef]

10. Singla, P.; Riyaz, M.; Singhal, S.; Goel, N. Theoretical study of adsorption of amino acids on graphene and BN sheet in gas and aqueous phase with empirical DFT dispersion N. correction. Phys. Chem. Chem. Phys. 2016, 18, 5597-5604. [CrossRef] [PubMed]

11. Costa, D.; Savio, L.; Pradier, C.-M. Adsorption of amino acids and peptides on metal and oxide surfaces in water environment: A synthetic and prospective review. J. Phys. Chem. B 2016, 120, 7039-7052. [CrossRef]

12. Wendisch, V.F. Metabolic engineering advances and prospects for amino acid production. Metab. Eng. 2020, 58, 17-34. [CrossRef]

13. Hermann, T. Industrial production of amino acids by coryneform bacteria. J. Biotechnol. 2003, 104, 155-172. [CrossRef]

14. Aghajanyan, A.E.; Hambardzumyan, A.A.; Vardanyan, A.A.; Saghiyan, A.S. Desalting of neutral amino acids fermentative solutions by electrodialysis with ion-exchange membranes. Desalination 2008, 228, 237-244. [CrossRef]

15. Readi, O.K.; Mengers, H.; Wiratha, W.; Wessling, M.; Nijmeijer, K. On the isolation of single acidic amino acids for biorefinery applications using electrodialysis. J. Membr. Sci. 2011, 384, 166-175. [CrossRef]

16. Readi, O.K.; Gironès, M.; Wiratha, W.; Nijmeijer, K. On the isolation of single basic amino acids with electrodialysis for the production of biobased chemicals. Ind. Eng. Chem. Res. 2012, 52, 1069-1078. [CrossRef]

17. Mangano, V.; Gervasi, T.; Rotondo, A.; De Pasquale, P.; Dugo, G.; Macrì, F.; Salvo, A. Protein hydrolysates from anchovy waste: Purification and chemical characterization. Nat. Prod. Res. 2021, 35, 399-406. [CrossRef] [PubMed]

18. Chen, C.W.; Whitlock, H.W. Molecular tweezers: A simple model of bifunctional intercalation. J. Am. Chem. Soc. 1978, 100, 4921-4922. [CrossRef]

19. Yemm, E.W.; Cocking, E.C.; Ricketts, R.E. The determination of amino-acids with ninhydrin. Analyst 1955, 80, 209-214. [CrossRef]

20. Ginn, H.E.; Frost, A.; Lacy, W.W. Nitrogen Balance in Hemodialysis Patients. Am. J. Clin. Nutr. 1968, 21, 385-393. [CrossRef]

21. Bolasco, P. Hemodialysis-Nutritional Flaws in Diagnosis and Prescriptions. Could Amino Acid Losses Be the Sharpest "Sword of Damocles"? Nutrients 2020, 12, 1773. [CrossRef] [PubMed]

22. Hendriks, F.K.; Kooman, J.P.; Van Loon, L.J. Dietary protein interventions to improve nutritional status in end-stage renal disease patients undergoing hemodialysis. Curr. Opin. Clin. Nutr. Metab. Care 2021, 24, 79-87. [CrossRef] [PubMed]

23. Martinez, D.; Sandeaux, R.; Sandeaux, J.; Gavach, C. Electrotransport of alanine through ion-exchange membranes. J. Membr. Sci. 1992, 69, 273-281. [CrossRef]

24. Eliseeva, T.V.; Shaposhnik, V.A.; Krisilova, E.V.; Bukhovets, A.E. Transport of basic amino acids through the ion-exchange membranes and their recovery by electrodialysis. Desalination 2009, 241, 86-90. [CrossRef]

25. Sandeaux, J.; Fares, A.; Sandeaux, R.; Gavach, C. Transport properties of electrodialysis membranes in the presence of arginine I. Equilibrium properties of a cation exchange membrane in an aqueous solution of arginine chlorhydrate and sodium chloride. J. Membr. Sci. 1994, 89, 73-81. [CrossRef]

26. Teng, Y.; Sanders, J.P.M.; Scott, E.L.; Van Zeeland, A.N.T. The use of l-lysine decarboxylase as a means to separate amino acids by electrodialysis. Green Chem. 2011, 13, 624-630. [CrossRef]

27. Fares, A.; Sandeaux, J.; Sandeaux, R.; Gavach, C. Transport properties of electrodialysis membranes in the presence of arginine II. Competition between the electrotransport of organic and inorganic ions through a cation exchange membrane in an aqueous solution of arginine chlorhydrate and sodium chloride. J. Membr. Sci. 1994, 89, 83-91. [CrossRef]

28. Firdaous, L.; Dhulster, P.; Amiot, J.; Gaudreau, A.; Lecouturier, D.; Kapel, R.; Lutin, F.; Vézina, L.-P.; Bazinet, L. Concentration and selective separation of bioactive peptides from an alfalfa white protein hydrolysate by electrodialysis with ultrafiltration membranes. J. Membr. Sci. 2009, 329, 60-67. [CrossRef]

29. Lentsch, S.; Aimar, P.; Orozco, J.L. Enhanced separation of albumin-poly(ethylene glycol) by combination of ultrafiltration and electrophoresis. J. Membr. Sci. 1993, 80, 221-232. [CrossRef]

30. Bargeman, G.; Houwing, J.; Recio, I.; Koops, G.-H.; Van Der Horst, C. Electro-membrane filtration for the selective isolation of bioactive peptides from an ?s2-casein hydrolysate. Biotechnol. Bioeng. 2002, 80, 599-609. [CrossRef]

31. Daufin, G.; Kerhervé, F.L.; Aimar, P.; Mollé, D.; Léonil, J.; Nau, F. Electrofiltration of solutions of amino acids or peptides. Le Lait 1995, 75, 105-115. [CrossRef]

32. Bargeman, G.; Dohmen-Speelmans, M.; Recio, I.; Timmer, M.; Van Der Horst, C. Selective isolation of cationic amino acids and peptides by electro-membrane filtration. Le Lait 2000, 80, 175-185. [CrossRef] 
33. Bargeman, G.; Koops, G.-H.; Houwing, J.; Breebaart, I.; Van Der Horst, H.; Wessling, M. The development of electro-membrane filtration for the isolation of bioactive peptides: The effect of membrane selection and operating parameters on the transport rate. Desalination 2002, 149, 369-374. [CrossRef]

34. Kimura, S.; Tamano, A. Separation of Aminoacids by Charged Ultrafiltration Membranes. In Membranes and Membrane Processes; Drioli, E., Nakagaki, M., Eds.; Springer Science and Business Media LLC: Berlin, Germany, 1986; pp. $191-197$.

35. Higuchi, A.; Hara, M.; Horiuchi, T.; Nakagawa, T. Optical resolution of amino acids by ultrafiltration membranes containing serum albumin. J. Membr. Sci. 1994, 93, 157-164. [CrossRef]

36. Tone, S.; Masawaki, T.; Hamada, T. The optical resolution of amino acids by ultrafiltration membranes fixed with plasma polymerized l-menthol. J. Membr. Sci. 1995, 103, 57-63. [CrossRef]

37. Nakao, S.; Osada, H.; Kurata, H.; Tsuru, T.; Kimura, S. Separation of proteins by charged ultrafiltration membranes. Desalination 1988, 70, 191-205. [CrossRef]

38. Gotoh, T.; Iguchi, H.; Kikuchi, K.-I. Separation of glutathione and its related amino acids by nanofiltration. Biochem. Eng. J. 2004, 19, 165-170. [CrossRef]

39. Timmer JM, K.; Speelmans MP, J.; Van Der Horst, H.C. Separation of amino acids by nanofiltration and ultrafiltration membranes. Sep. Purif. Technol. 1998, 14, 133-144. [CrossRef]

40. Garem, A.; Daufin, G.; Maubois, J.L.; Leonil, J. Selective separation of amino acids with a charged inorganic nanofiltration membrane: Effect of physicochemical parameters on selectivity. Biotechnol. Bioeng. 1996, 54, 291-302. [CrossRef]

41. Hong, S.U.; Bruening, M.L. Separation of amino acid mixtures using multilayer polyelectrolyte nanofiltration membranes. J. Membr. Sci. 2006, 280, 1-5. [CrossRef]

42. Vyas, B.; Ray, P. Preparation of nanofiltration membranes and relating surface chemistry with potential and topography: Application in separation and desalting of amino acids. Desalination 2015, 362, 104-116. [CrossRef]

43. Wang, X.-L.; Ying, A.-L.; Wang, W.-N. Nanofiltration of 1-phenylalanine and l-aspartic acid aqueous solutions. J. Membr. Sci. 2002, 196, 59-67. [CrossRef]

44. Yoshikawa, M.; Izumi, J.-I.; Kitao, A.T.; Sakamoto, S. Molecularly imprinted polymeric membranes containing DIDE derivatives for optical resolution of amino acids. Macromolecules 1996, 29, 8197-8203. [CrossRef]

45. Lin, S.-H.; Chen, C.-N.; Juang, R.-S. Extraction equilibria and separation of phenylalanine and aspartic acid from water with di(2-ethylhexyl)phosphoric acid. J. Chem. Technol. Biotechnol. 2006, 81, 406-412. [CrossRef]

46. Capela, E.V.; Quental, M.V.; Domingues, P.; Coutinho, J.A.P.; Freire, M.G. Effective separation of aromatic and aliphatic amino acid mixtures using ionic-liquid-based aqueous biphasic systems. Green Chem. 2017, 19, 1850-1854. [CrossRef] [PubMed]

47. Fukumoto, K.; Yoshizawa, M.; Ohno, H. Room temperature ionic liquids from 20 natural amino acids. J. Am. Chem. Soc. 2005, 127, 2398-2399. [CrossRef]

48. Esfahani, M.R.; Aktij, S.A.; Dabaghian, Z.; Firouzjaei, M.D.; Rahimpour, A.; Eke, J.; Escobar, I.C.; Abolhassani, M.; Greenlee, L.F.; Esfahani, A.R.; et al. Nanocomposite membranes for water separation and purification: Fabrication, modification, and applications. Sep. Purif. Technol. 2019, 213, 465-499. [CrossRef]

49. Yue, X.; Li, Z.; Zhang, T.; Yang, D.; Qiu, F. Design and fabrication of superwetting fiber-based membranes for oil/water separation applications. Chem. Eng. J. 2019, 364, 292-309. [CrossRef]

50. Wang, G.; Zhang, C.; Sun, M.; Zhang, X.; Wu, C.; Wu, Y. Separation of mixed amino acids by BMED process using porous SPES and SPSf cation exchange membranes. Sep. Purif. Technol. 2017, 188, 539-547. [CrossRef]

51. Chen, S.; Lv, C.; Hao, K.; Jin, L.; Xie, Y.; Zhao, W.; Sun, S.; Zhang, X.; Zhao, C. Multifunctional negatively-charged poly (ether sulfone) nanofibrous membrane for water remediation. J. Colloid Interface Sci. 2019, 538, 648-659. [CrossRef]

52. Ingole, P.G.; Bajaj, H.C.; Singh, K. Membrane separation processes: Optical resolution of lysine and asparagine amino acids. Desalination 2014, 343, 75-81. [CrossRef]

53. Ji, Y.-L.; Qian, W.-J.; An, Q.-F.; Lee, K.-R.; Gao, C.-J. Polyelectrolyte nanoparticles based thin-film nanocomposite (TFN) membranes for amino acids separation. J. Ind. Eng. Chem. 2018, 66, 209-220. [CrossRef]

54. Stepniak, P.; Lainer, B.; Chmurski, K.; Jurczak, J. pH-Controlled recognition of amino acids by urea derivatives of $\beta$-cyclodextrin. RSC Adv. 2017, 7, 15742-15746. [CrossRef]

55. Liu, L.; Yang, L.-L.; Jin, K.-Y.; Xu, D.-Q.; Gao, C.-J. Recovery of 1-tryptophan from crystallization wastewater by combined membrane process. Sep. Purif. Technol. 2009, 66, 443-449. [CrossRef]

56. Bukhovets, A.; Savel'Eva, A.; Eliseeva, T. Separation of amino acids mixtures containing tyrosine in electromembrane system. Desalination 2009, 241, 68-74. [CrossRef]

57. Lammens, T.M.; De Biase, D.; Franssen, M.C.R.; Scott, E.L.; Sanders, J.P.M. The application of glutamic acid $\alpha$-decarboxylase for the valorization of glutamic acid. Green Chem. 2009, 11, 1562-1567. [CrossRef]

58. Kyne, G.M.; Light, M.E.; Hursthouse, M.B.; De Mendoza, J.; Kilburn, J.D. Enantioselective amino acid recognition using acyclic thiourea receptors. J. Chem. Soc. Perkin Trans. 1 2001, 1, 1258-1263. [CrossRef]

59. Mutihac, L.; Lee, J.H.; Kim, J.S.; Vicens, J. Recognition of amino acids by functionalized calixarenes. Chem. Soc. Rev. 2011, 40, 2777-2796. [CrossRef] [PubMed]

60. Kumar, R.; Vikramachakravarthi, D.; Pal, P. Production and purification of glutamic acid: A critical review towards process intensification. Chem. Eng. Process. Process. Intensif. 2014, 81, 59-71. [CrossRef] 
61. Fähnrich, A.; Mavrov, V.; Chmiel, H. Membrane processes for water reuse in the food industry. Desalination 1998, 119, $213-216$. [CrossRef]

62. Drioli, E.; Romano, M. Progress and new perspectives on integrated membrane operations for sustainable industrial growth. Ind. Eng. Chem. Res. 2001, 40, 1277-1300. [CrossRef]

63. Mavrov, V.; Chmiel, H.; Bélières, E. Spent process water desalination and organic removal by membranes for water reuse in the food industry. Desalination 2001, 138, 65-74. [CrossRef]

64. Ferreira, A.R.V.; Alves, V.D.; Coelhoso, I.M. Polysaccharide-Based Membranes in Food Packaging Applications. Membranes 2016, 6, 22. [CrossRef]

65. Ghaseminezhad, S.M.; Barikani, M.; Salehirad, M. Development of graphene oxide-cellulose acetate nanocomposite reverse osmosis membrane for seawater desalination. Compos. Part B Eng. 2019, 161, 320-327. [CrossRef]

66. Ghimpusan, M.; Nechifor, G.; Din, I.S.; Nechifor, A.C.; Passeri, P. Application of hollow fibre membrane bioreactor instead of granular activated carbon filtration for treatment of wastewater from car dismantler activity. Mat. Plast. 2016, 53, 578-584.

67. Nechifor, A.; Cotorcea, S.; Bungău, C.; Albu, P.; Pașcu, D.; Oprea, O.; Grosu, A.; Pîrțac, A.; Nechifor, G. Removing of the sulfur compounds by impregnated polypropylene fibers with silver nanoparticles-cellulose derivatives for air odor correction. Membranes 2021, 11, 256. [CrossRef] [PubMed]

68. Din, I.S.; Cimbru, A.M.; Rikabi, A.A.K.K.; Tanczos, S.K.; Cotorcea, S.T.; Nechifor, G. Iono-molecular separation with composite membranes VI. Nitro-phenol separation through sulfonated polyether ether ketone on capillary polypropylene membranes. Rev. Chim. 2018, 69, 1603-1607. [CrossRef]

69. Nafliu, I.M.; Al Ani HN, A.; GROSU, A.R.; Tanczos, S.K.; Maior, I.; Nechifor, A.C. Iono-molecular separation with composite membranes. VII. nitrophenols pertraction on capilary polypropylene S-EPDM composite membranes. Mater. Plast. 2018, 55, 511-516. [CrossRef]

70. Ghimpusan, M.; Nechifor, G.; Nechifor, A.-C.; Dima, S.-O.; Passeri, P. Case studies on the physical-chemical parameters' variation during three different purification approaches destined to treat wastewaters from food industry. J. Environ. Manag. 2017, 203, 811-816. [CrossRef]

71. Grosu, A.R.; Nafliu, I.M.; Din, I.S.; Cimbru, A.M.; Nechifor, G. Neutralization with simultaneous separation of aluminum and copper ions from condensed water through capillary polypropylene and cellulose. UPB Sci. Bull. Ser. B Chem. Mater. Sci. 2020, 82, 25-34.

72. Subroto, E.; Lembong, E.; Filianty, F.; Indiarto, R.; Primalia, G.; Putri, M.S.K.Z.; Theodora, H.C.; Junar, S. The Analysis Tech-niques Of Amino Acid And Protein In Food And Agricultural Products. Int. J. Sci. Technol. Res. 2020, 9, 29-36.

73. Croxton, R.; Kent, T.; Littlewood, A.; Smith, M. An evaluation of inkjet printed amino acid fingerprint test targets for ninhydrin process monitoring - and some observations. Forensic Sci. Int. 2021, 321. [CrossRef]

74. Chen, L.; Chen, Q.; Zhang, Z.; Wan, X. A novel colorimetric determination of free amino acids content in tea infusions with 2,4-dinitrofluorobenzene. J. Food Compos. Anal. 2009, 22, 137-141. [CrossRef]

75. Koter, S.; Szczepański, P.; Mateescu, M.; Nechifor, G.; Badalau, L.; Koter, I. Modeling of the cadmium transport through a bulk liquid membrane. Sep. Purif. Technol. 2013, 107, 135-143. [CrossRef]

76. Szczepański, P.; Diaconu, I. Transport ofp-nitrophenol through an agitated bulk liquid membrane. Sep. Sci. Technol. 2012, 47, 1725-1732. [CrossRef]

77. Kowalski, M.; Salerno-Kochan, R. An effect of washing on durability of hydrophobic finishes of membrane laminates. Autex Res. J. 2018, 18, 137-142. [CrossRef] 